San Jose State University

SJSU ScholarWorks

Master's Theses

Master's Theses and Graduate Research

Fall 2010

\title{
Clast Provenance Constraints, Late Cretaceous Pigeon Point Formation, California
}

Anne Sanquini

San Jose State University

Follow this and additional works at: https://scholarworks.sjsu.edu/etd_theses

\section{Recommended Citation}

Sanquini, Anne, "Clast Provenance Constraints, Late Cretaceous Pigeon Point Formation, California" (2010). Master's Theses. 3893.

DOI: https://doi.org/10.31979/etd.gbfk-zfc9

https://scholarworks.sjsu.edu/etd_theses/3893

This Thesis is brought to you for free and open access by the Master's Theses and Graduate Research at SJSU ScholarWorks. It has been accepted for inclusion in Master's Theses by an authorized administrator of SJSU ScholarWorks. For more information, please contact scholarworks@sjsu.edu. 


\title{
CLAST PROVENANCE CONSTRAINTS, LATE CRETACEOUS PIGEON POINT FORMATION, CALIFORNIA
}

\author{
A Thesis \\ Presented to \\ The Faculty of the Department of Geology \\ San José State University \\ In Partial Fulfillment \\ of the Requirements for the Degree \\ Master of Science
}

by

Anne Sanquini

December 2010 
(C) 2010

Anne Sanquini

ALL RIGHTS RESERVED 
The Designated Thesis Committee Approves the Thesis Titled
CLAST PROVENANCE CONSTRAINTS, LATE CRETACEOUS PIGEON POINT FORMATION, CALIFORNIA
by
Anne Sanquini

\begin{abstract}
APPROVED FOR THE DEPARTMENT OF GEOLOGY
\end{abstract}
SAN JOSÉ STATE UNIVERSITY

December 2010
Dr. Ellen P. Metzger
Department of Geology
Robert J. McLaughlin
United States Geological Survey
Dr. Richard L. Sedlock
Department of Geology 


\section{ABSTRACT \\ CLAST PROVENANCE CONSTRAINTS, LATE CRETACEOUS PIGEON POINT FORMATION, CALIFORNIA \\ by Anne Sanquini}

The depositional location of the Late Cretaceous Pigeon Point Formation, which crops out between San Francisco and Santa Cruz on the California coast, is unknown. Petrographic and chemical analysis of the conglomeratic clasts in the formation revealed several types of clasts that were helpful to constrain provenance. These included clasts of the recently identified underlying Pescadero felsite, clasts of dark porphyries with salmon-colored phenocrysts that have been identified at four other depositional locations, and granitoids for which isotopic data existed.

Synthesis of research performed for this thesis with previously published data leads to a hypothesis that suggests the Pigeon Point Formation was deposited in the mid-Campanian at a paleolatitude south of the current United States, onto the Pescadero felsite, in an accretionary complex setting. By the late Miocene, it was transported northward to a position near the present-day location of San Luis Obispo, then brought to its current location, within the past $10 \mathrm{Ma}$, by dextral slip on the San Gregorio-Hosgri fault and the San Andreas fault system. 


\section{ACKNOWLEDGEMENTS}

Thank you to my thesis advisor, Ellen Metzger, for her thoughtful and patient support throughout this project, and to my thesis committee members Bob McLaughlin, who introduced me to this area and provided inspiration and constructive criticism along the way, and Richard Sedlock, for his enthusiastic and thorough review of the text.

Many experts generously shared of their knowledge. Thank you to Karen Grove, Don Lowe, Diane Moore, Gary Ernst, Dave Anderson, Robert Lopez, Kathleen Burnham, Cal Stevens, Carl Jacobson, Duane Champion, Gail Mahood, Rick Stanley, Russ Graymer, and Rolfe Erickson.

I appreciate the quick availability of permits from the State of California department of Parks and Recreation for geological investigations and collections, and I am also grateful for access given by Susan and Ken Miller to collect samples on their property.

Thank you to my fellow students: to field assistants Rachel Unger, Morgan Mendoza, Ryan McKee, and Elaine Miller, as well as to Brendon Johnson, who assisted with several of the illustrations.

Finally, thank you to my spouse, Richard Sanquini, who just now walked by and said he would be glad to have me back, soon. 


\section{TABLE OF CONTENTS}

INTRODUCTION

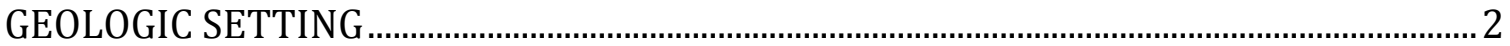

Fault Relationships .....................................................................................................

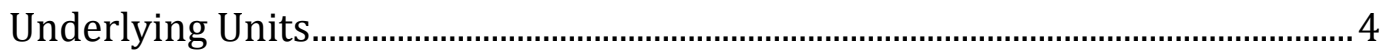

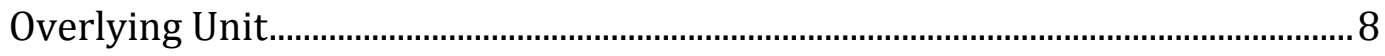

PREVIOUS WORK ON THE PIGEON POINT FORMATION …………….....................................

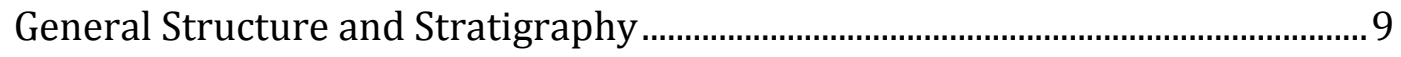

Paleontology and Palynology ................................................................................... 11

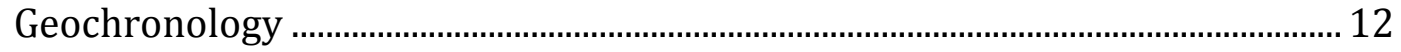

Conglomerate Clasts ……........................................................................................ 12

Paleomagnetic Data.................................................................................................. 14

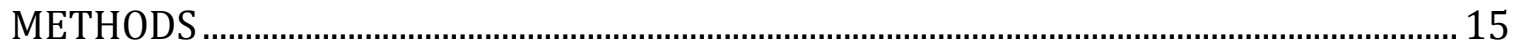

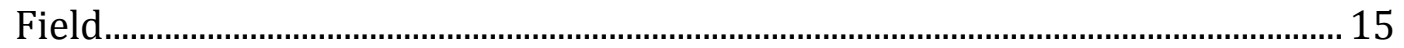

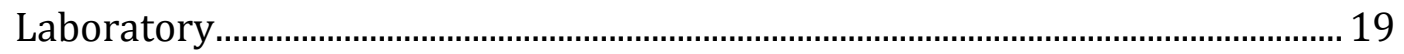


PETROGRAPHIC OBSERVATIONS....................................................................................... 20

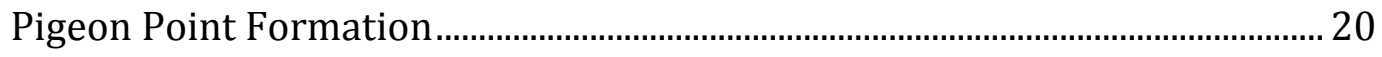

Vaqueros(?) Formation ............................................................................................ 24

MAJOR AND TRACE ELEMENT CHEMISTRY ……………................................................... 27

Pescadero Felsite Samples.......................................................................................... 27

"Smoked Salmon" Clasts................................................................................................... 30

INTERPRETATION OF DATA................................................................................................ 32

Age of Pigeon Point Conglomerates and Timing of Key Events ........................... 32

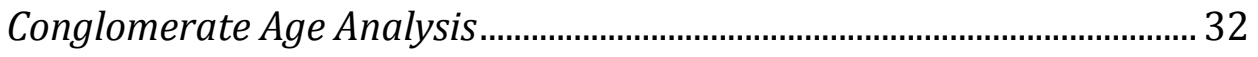

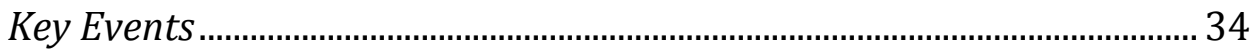

Linkage to Underlying Units...................................................................................... 35

Comparison to Overlying Unit .............................................................................. 37

Comparison to Upper Cretaceous Atascadero Formation ..................................... 38

Paleontology and Inferred Paleolatitudes...................................................38

Underlying Rocks Differ ........................................................................... 39

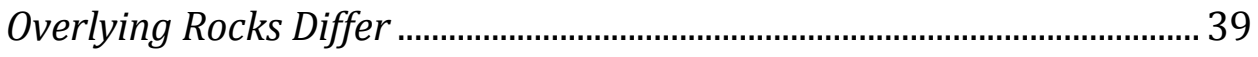

vii 
Depositional Locations of the "Smoked Salmon" Clasts ............................................ 40

Synthesis of Depositional Environment .................................................................... 41

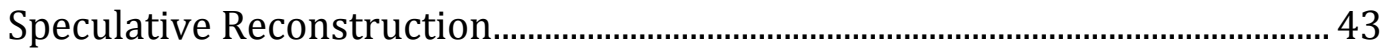

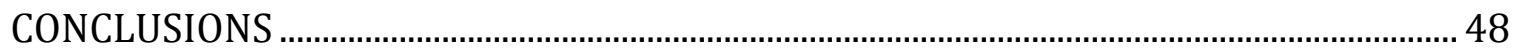

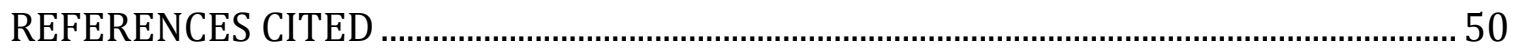




\section{LIST OF FIGURES}

Figure

1. Key faults, locations and geologic units mentioned in text ............................................. 3

2. Local geologic map, including fossil and zircon sampling locations ............................6

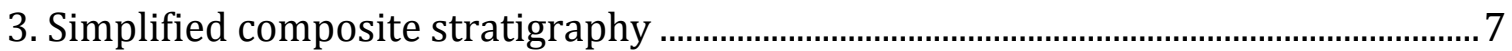

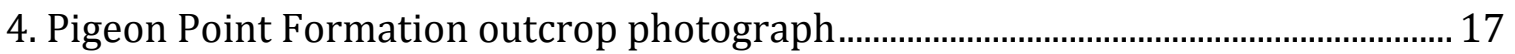

5. Vaqueros(?) Formation outcrop photograph................................................................ 18

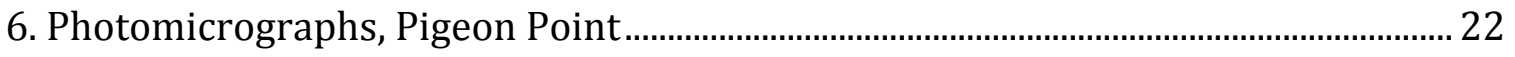

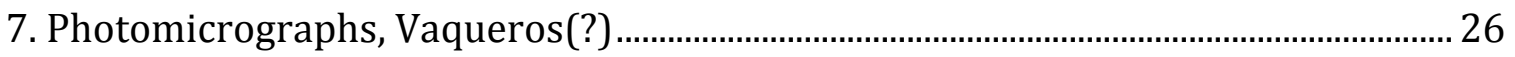

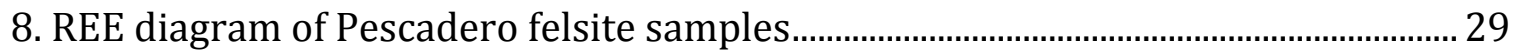

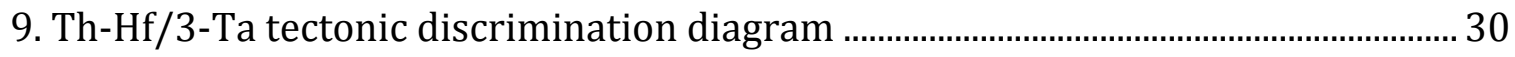

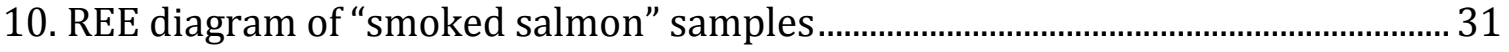

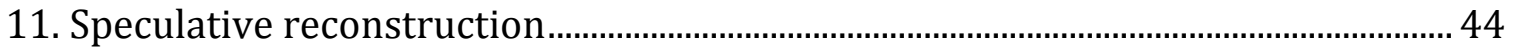




\section{LIST OF TABLES}

Table

1. Whole-rock strontium isotope compositions …………………………………………..9

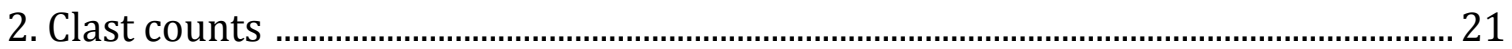

3. Chemical composition of selected clasts ……………....................................................... 28

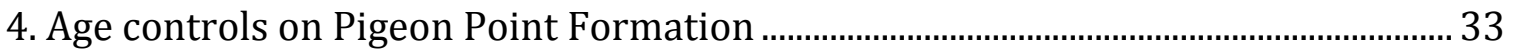

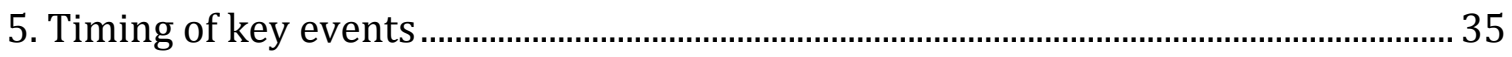

6. Volcanic ages, north Channel Islands and Vaqueros(?) basalts .................................. 47 


\section{INTRODUCTION}

The objective of this research is to characterize the petrography and chemistry of igneous clasts in the Pigeon Point Formation and to use these data to constrain their provenance. Located on the central California coast, the Pigeon Point Formation has been transported to its current location by a complex set of fault dynamics; determination of clast provenance may partly clarify the tectonic history of western California since the Late Cretaceous period.

Petrographic and chemical study of the clasts in the Pigeon Point Formation was used to link some of the clasts to other, possibly correlative locations. These analyses included the determination of overall composition, phenocryst mineralogy, mineral assemblages indicative of degree of metamorphism, and textural properties of the clasts. After a literature review to identify those rocks from other locations that may be correlative with distinctive clasts from the Pigeon Point Formation, selected samples were analyzed for major and rare earth elements (REE).

Published paleontologic, palynologic, paleomagnetic, strontium, and $\mathrm{U}-\mathrm{Pb}$ zircon age data for elements of the Pigeon Point Formation helped to constrain possible locations at time of deposition. Fault location, timing, and direction and amount of slip were considered in terms of which hypotheses are best supported by the multiple lines of evidence. 


\section{GEOLOGIC SETTING}

\section{Fault Relationships}

The Pigeon Point Formation lies to the west of the San Gregorio-Hosgri fault on the Pigeon Point block (Figure 1) and is exposed in a belt less than $3 \mathrm{~km}$ wide, for about 16 km from Pescadero State Beach to Point Año Nuevo (Hall et al., 1959). Its top has been eroded. It is overlain in faulted unconformity by the late Oligoceneearly Miocene Vaqueros(?) Formation (Taylor, 1988) and by the Miocene-Pliocene Purisima Formation (Powell et al., 2007). The bottom of the Pigeon Point Formation is locally underlain, in sheared contact, by $\sim 86-90$ Ma felsitic volcanic rocks exposed west of the town of Pescadero, informally named the Pescadero felsite (Ernst et al., 2009).

The right-slip San Gregorio-Hosgri fault is part of the larger San Andreas fault system. Estimates of total dextral slip on the San Gregorio-Hosgri fault range from 150-160 km (Clark, 1998; Dickinson et al., 2005) to as high as $180 \mathrm{~km}$ (Burnham, 2005, 2009). Most studies consider all slip on the San Gregorio-Hosgri fault to have occurred in the last 10 m.y., but some studies assign most slip to pre-Neogene time (e.g. Underwood et al., 1995). 


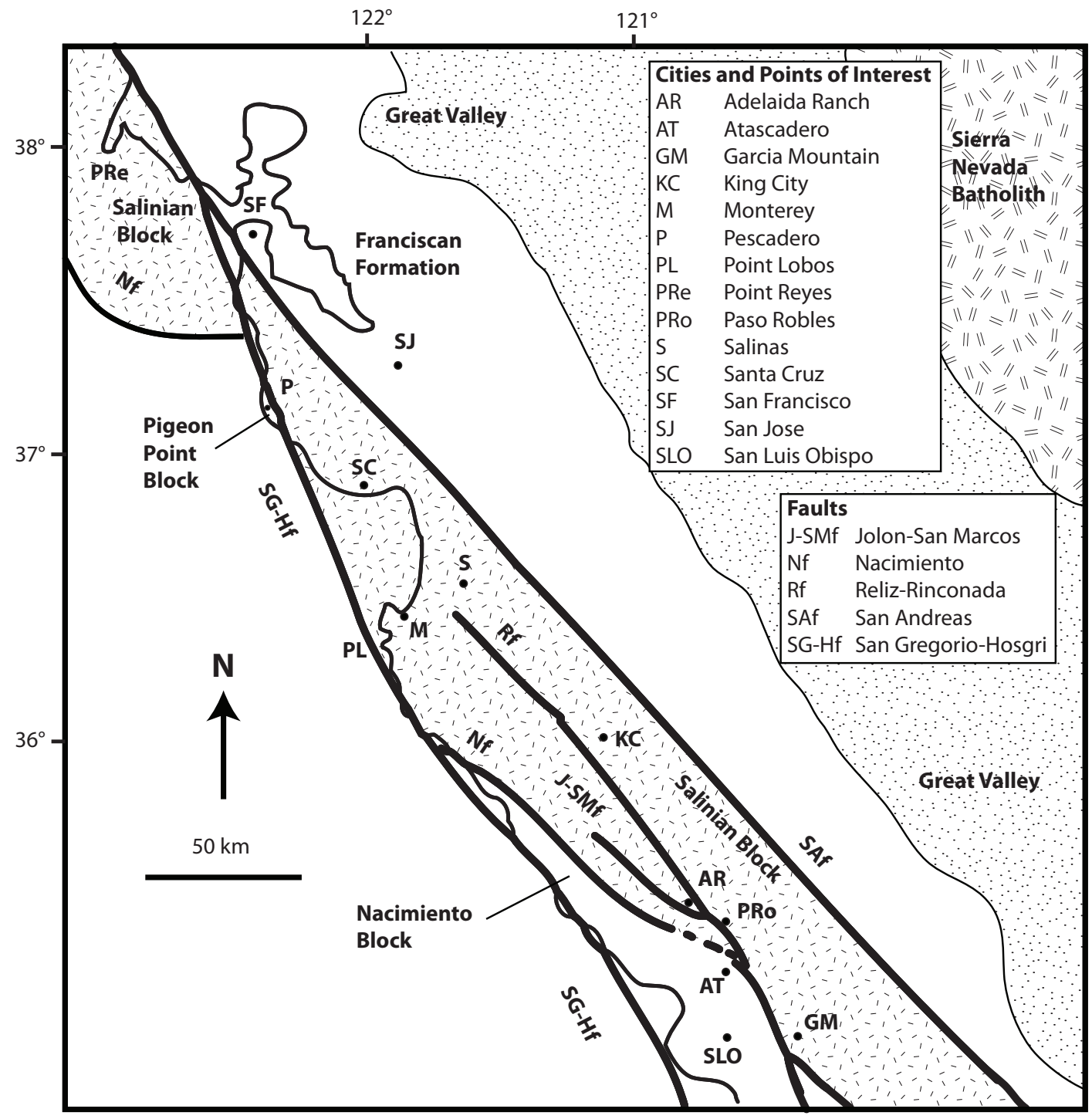

Figure 1. Key faults, locations and geologic units mentioned in text. Location of offset Nacimiento fault after Dickinson et al. (2005). Simplified from Jennings (1977). 
A match of some truncated aeromagnetic anomalies across the San GregorioHosgri fault suggests that the San Gregorio-Hosgri fault offsets the Nacimiento fault to a location just north of Pescadero (Robert Jachens, pers. comm.). Dickinson et al. (2005) instead interpreted an offshore discontinuity located somewhat further to the north (Figure 1) to be the offset Nacimiento fault. The Nacimiento fault (Gilbert, 1973a; Page, 1981) separates Salinian granitic basement to the northeast from the Franciscan Complex plus ophiolitic rocks of the Nacimiento block to the southwest (Figure 1). The Nacimiento block is also known as the Sur-Obispo terrane (Vedder et al., 1983). Dickinson et al. (2005) estimated that offset on the Nacimiento fault initiated at $75 \mathrm{Ma}$ continuing to $\sim 52 \mathrm{Ma}$ and suggested sinistral slip of 500-600 km. Others (e.g. Hall, 1991; Powell, 1993) interpreted the Nacimiento as a thrust fault while still others (e.g. Page, 1981; Vedder et al., 1991) inferred dextral slip or some combination of the above. The fault has been overprinted by younger tectonic activity. Vedder et al. (1991) suggested significant dextral slip along the Rinconada section of the Nacimiento fault, probably during the Oligocene.

\section{Underlying Units}

Many workers have suggested that the Pigeon Point Formation may lie on Salinian basement (Clark and Brabb, 1978; Lowe, 1979 and 2004; Howell and Joyce, 
1981; Champion et al., 1984). However, Lee-Wong and Howell (1977) noted that the plagioclase to total feldspar ratios $(\mathrm{P} / \mathrm{F})$ of sandstones sampled from the Salinian block range from 0.43 to 0.55 whereas the Pigeon Point Formation P/F ratio is 0.73 , within the 0.65 to $0.77 \mathrm{P} / \mathrm{F}$ range of sandstones sampled from the Nacimiento block. Furthermore, Grove (1989), Whidden et al. (1998), and Dickinson et al. (2005) associated the conglomerate clast composition and Late Cretaceous depositional age of the Pigeon Point Formation with accretionary prism and forearc material of the Franciscan Assemblage of the Nacimiento block, and Kistler and Champion (2001) noted that the more primitive initial ${ }^{87} \mathrm{Sr} /{ }^{86} \mathrm{Sr}$ isotope ratios of the granitoid clasts in the Pigeon Point formation are not typical of the Salinian block.

Restoration of the offset Nacimiento fault places the Pigeon Point Formation to the southwest of the fault and thus on the Nacimiento block, but the depositional basement of the Pigeon Point Formation is not exposed. Locally, based on age and field relations (Figures 2 and 3), the Pigeon Point Formation is inferred to overlie the $\sim 86-90$ Ma Pescadero felsite, which erupted into an accretionary complex (Ernst et al., in press). Sanquini et al. (2010) determined that $\sim 5$ percent of the clasts sampled in a conglomerate unit of the Pigeon Point Formation appear to be a match with the underlying Pescadero felsite. 


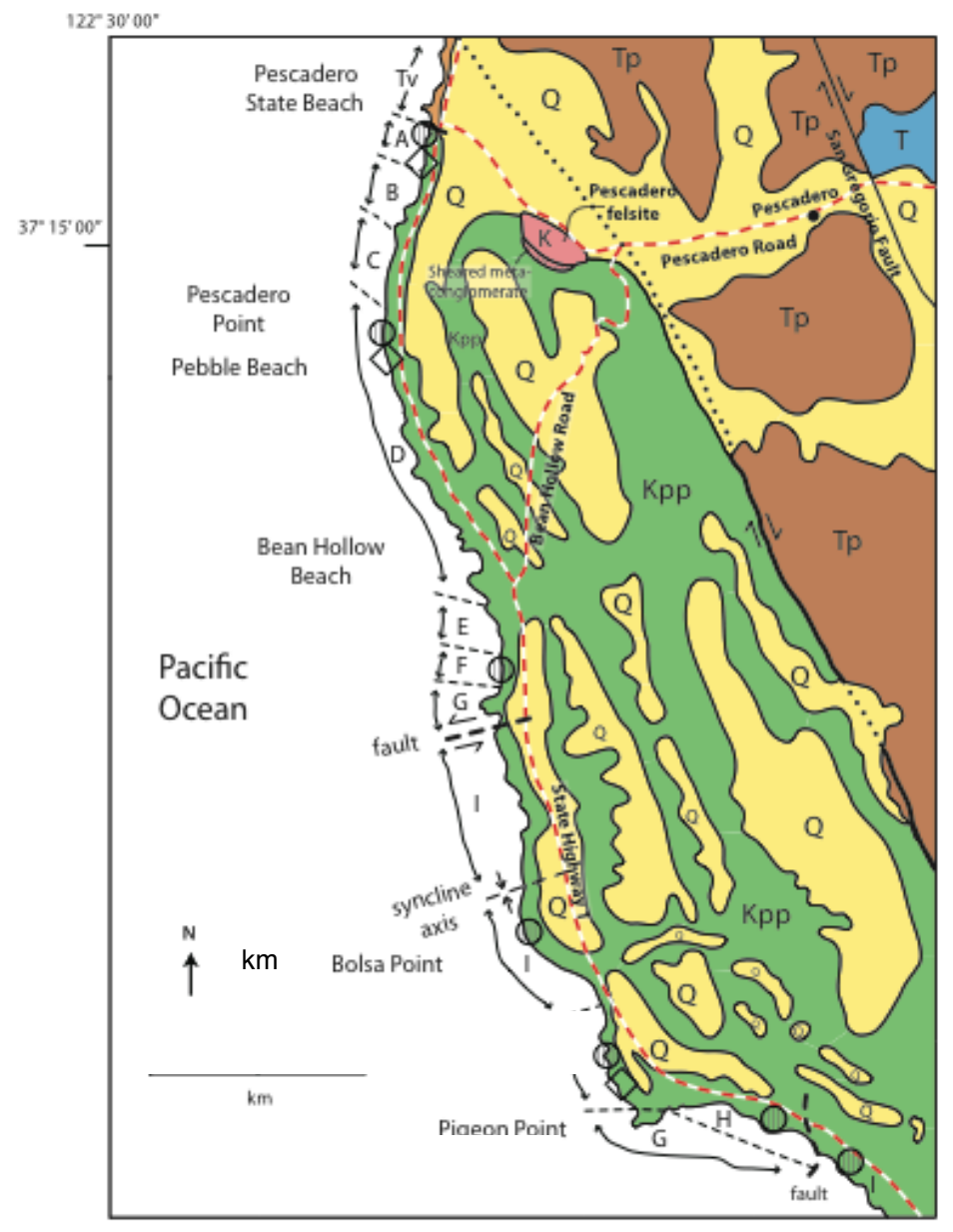

EXPLANATION

$\sim$ Contact

-* Fault

, Road

(1) Fossil sample locations of Elder and Saul (1993)

$\diamond$ Zircon sample locations of Jacobsen et al. (2010)

$\therefore$ Pigeon Point Formation

$\because C$ ' member along beach, Lowe (2004)

Q Quaternary deposits

TD Purisima Formation (Pliocene)

Pre-Purisima deposits (Miocene and older)

iv Vaqueros (?) Formation (late Oligocene-early Miocene)

Pigeon Point Formation (Late Cretaceous)

Sheared metaconglomerate (Late Cretaceous)

Pescadero felsite

(Late Cretaceous)

Figure 2. Local geologic map, including fossil and zircon sampling locations. Modified from Taylor (1988), Lowe (2004), and Ernst et al. (2009). Geologic map simplified from Brabb et al. (2000). 


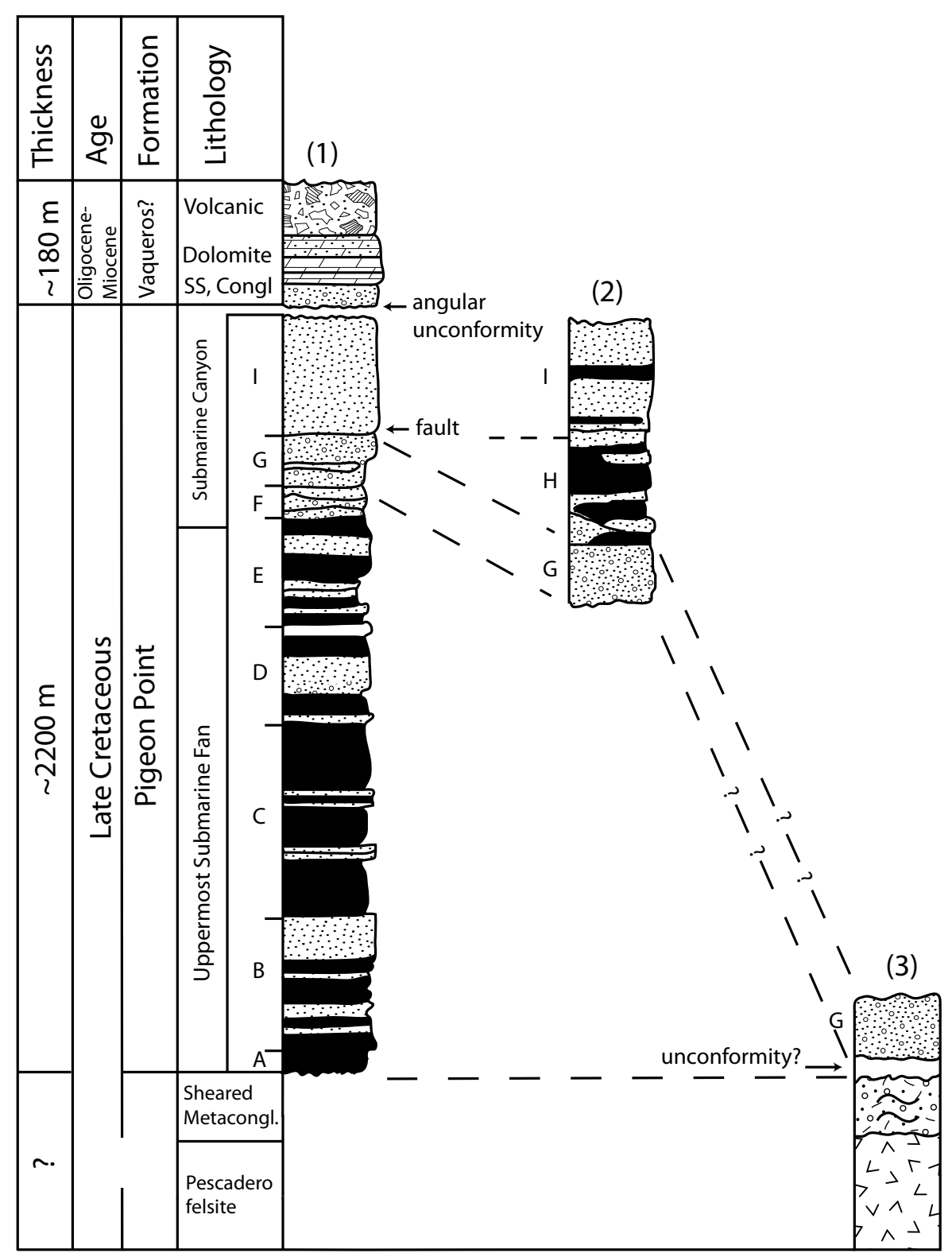

Figure 3. Simplified composite stratigraphy. (1). Northern sequence of Pigeon Point Formation, outcrops from Bolsa Point syncline axis to Pescadero Beach, plus Vaqueros(?) Formation. (2). Southern sequence, outcrops from syncline axis to Pigeon Point. (3). Inland exposure of Pigeon Point Formation and Pescadero felsite. See Figure 2 for locations. Modified from Taylor (1988), Lowe $(1979,2004)$ and Ernst et al. (2009). 


\section{Overlying Unit}

The Vaqueros(?) Formation (Davis, 1955; Hall et al., 1959; Clark and Brabb, 1978) overlies the Pigeon Point Formation in an angular, faulted unconformity exposed at Pescadero State Beach (Figure 2). Granitic boulders at the base of the formation are overlain by conglomeratic interbeds containing well-rounded felsic volcanic, granitic, and quartzite pebbles and cobbles in an arkosic sandstone matrix (Clark and Brabb, 1978), and by plane-laminated sandstone beds (Taylor, 1988). Taylor noted a mean 0.52 ratio of plagioclase to total feldspars in the Vaqueros(?) sandstones, within the 0.43 to $0.55 \mathrm{P} / \mathrm{F}$ range of Salinian block sandstones sampled by Lee-Wong and Howell (1977). Taylor interpreted the formation as a regressive beach sequence. Mafic volcanic deposits include breccias, pillows, and flows, some of which are interstratified with the sandstone beds. Some mafic units are peperites, which form where magma contacts unconsolidated submarine sediments. Taylor used a 22.0 \pm 0.7 Ma (K-Ar) age on peperites and "Vaqueros Stage" megafossils to infer a late Oligocene-early Miocene depositional age. Initial ${ }^{87} \mathrm{Sr} /{ }^{86} \mathrm{Sr}$ strontium isotope ratios reported by Kistler and Champion (2001) from the granitoid clasts of the Vaqueros(?) Formation (Table 1) suggest a transitional to evolved magma source. 
Table 1. Whole-rock strontium isotope compositions. Kistler and Champion (2001).

\begin{tabular}{|l|l|l|}
\hline Vaqueros(?) Formation & ${ }^{87} \mathrm{Sr} /{ }^{86} \mathrm{Sr}$ measured & ${ }^{87} \mathrm{Sr} /{ }^{86} \mathrm{Sr}$ initial \\
\hline $\begin{array}{l}\text { Fine grained granitoid cobbles, } \\
\mathrm{n}=2\end{array}$ & $0.71246,0.74448$ & 0.71200 \\
\hline $\begin{array}{l}\text { Fine grained granitoid cobbles, } \\
\mathrm{n}=6\end{array}$ & 0.71042 to 0.73909 & 0.70923 \\
\hline $\begin{array}{l}\text { Coarse grained granitoid } \\
\text { cobbles, } \mathrm{n}=4\end{array}$ & 0.70642 to 0.70686 & 0.70599 to 0.70637 \\
\hline Pigeon Point Formation & ${ }^{87} \mathrm{Sr} /{ }^{86} \mathrm{Sr}$ measured & $87 \mathrm{Sr} /{ }^{86} \mathrm{Sr}$ initial \\
\hline Granitoid cobbles, $\mathrm{n}=6$ & 0.70483 to 0.70608 & 0.70468 to 0.70571 \\
\hline
\end{tabular}

\section{PREVIOUS WORK ON THE PIGEON POINT FORMATION}

\section{General Structure and Stratigraphy}

The narrow exposure of the Pigeon Point Formation along the coast is cut by many faults (Howell and Joyce, 1981). It is also tilted and folded, and some blocks 
within the formation have been rotated (Joyce, 1981). As a result, any exact reconstruction of the stratigraphy is difficult, and estimates of minimum total thickness range from $2200 \mathrm{~m}$ (Lowe, 1979, 2004) to 3300 m (Howell et al., 1977, Howell and Joyce, 1981).

On a broad structural level, the Pigeon Point Formation is divided into northern and southern sections (Figures 2 and 3). The oldest rocks, member A of Lowe 2004, are dominantly thin-bedded turbidites and are exposed only in the northern section, at Pescadero State Beach. The stratigraphy of this northern section continues upsection through a sequence of uppermost submarine fan to submarine canyon members identified by Lowe $(1979,2004)$. A 175-m-thick, wellstratified pebble and conglomerate lens, member G of Lowe, 1979 and 2004, marks the beginning of a canyon-fill sequence, and crops out in the upper part of the northern section, exposed about $1 \mathrm{~km}$ south of Bean Hollow State Beach. Member G has been correlated (Howell and Joyce, 1981) with a unit in the southern section, exposed at Pigeon Point. The upper units of the northern section are repeated in the southern section of the formation either by slip on a fault about $2 \mathrm{~km}$ north of Bolsa Point, (Howell and Joyce, 1981) or by folding about the axis of a broad syncline about $1 \mathrm{~km}$ north of Bolsa Point (Figure 2). 


\section{Paleontology and Palynology}

Elder and Saul (1993) identified molluscan assemblages in the Pigeon Point Formation and compared them to species at several other localities.

Paleogeographic interpretation of molluscan temperature indicators suggests an early to middle Campanian age of deposition in a warm-temperate to subtropical climate (Elder and Saul, 1983; Saul and Squires, 2008). Of ten compared localities, Elder and Saul (1993) concluded that the Pigeon Point Formation best correlated with the five most southern locations, from Santa Barbara to Mexico, and that the Santa Ana Mountains of the Peninsular Ranges had the strongest overall match. Notably, the warm-climate Volutoderma santana present at Pigeon Point is not otherwise found north of the Santa Ana Mountains (Elder and Saul, 1993; Saul and Squires, 2008). Hall at al. (1959) identified a Maastrichtian fossil in the Pigeon Point Formation; however, subsequent workers were not able to confirm that identification.

A palynologic study by Frederiksen (1990) suggested that the Pigeon Point Formation was deposited at a latitude south of the present United States, which is consistent with the paleontologic studies. 


\section{Geochronology}

Detrital zircon dating from the Pigeon Point Formation, based on 39 ages from three samples, suggested a lower age limit for the formation of $85 \pm 5 \mathrm{Ma}$ (Jacobson et al., in press). A younger detrital zircon age of $73 \pm 4$ Ma was interpreted by the authors as an outlier, whereas the $~ 85 \mathrm{Ma}$ age is part of a cluster and thus more representative. Figure 2 depicts zircon as well as fossil sampling locations.

\section{Conglomeratic Clasts}

Several workers have counted Pigeon Point Formation clasts to various levels of detail (Tyler, 1972; Howell and Vedder, 1978; Howell and Joyce, 1981; Bachman and Abbott, 1988; Burnham, 1998c; Grove, 1989; Seiders and Cox, 1989). All noted an abundance of well-rounded silicic volcanic clasts, comprising $\sim 45$ percent and up to 90 percent of the clast population, depending on location, sampling, and classification criteria used by the worker. 
Grove (1989) noted that clasts from the Pigeon Point Formation differ somewhat from clasts to the south from the Salinian block, and suggested that the Pigeon Point Formation may be part of the Sur-Obispo terrane. Grove also documented Late Jurassic radiolarian chert clasts in the formation.

Clark and Brabb (1978) thought some of the clasts of the Pigeon Point Formation bore a similarity to the Pescadero felsite (Ernst et al., 2009) exposed near the town of Pescadero. That relationship was subsequently confirmed by Ernst et al. (2009) and by Sanquini et al. (2010).

Bachman and Abbott (1988) and Burnham (1998c, 2005) noted abundant clasts composed of salmon-colored potassium feldspar phenocrysts in a dark gray aphanitic groundmass at Point Lobos and Point Reyes but not identified in the Pigeon Point Formation. This clast type is noted in this section because, as described later, a potential correlative was discovered in the Pigeon Point Formation as part of the research for this thesis. In addition to Point Lobos and Point Reyes, Bachman and Abbott (1988) identified this clast type at Adelaida Ranch, about $15 \mathrm{~km}$ west of Paso Robles, and at locations near Garcia Mountain, about $30 \mathrm{~km}$ east of San Luis Obispo (Figure 1). These four basins are all late Paleocene-early Eocene (Clark et al., 1984; Bachman and Abbott, 1988). The distinctive clasts were named "smoked salmon" for the pink phenocrysts by Bachman and Abbott (1988) whereas Burnham (2005) referred to them as "purple porphyry" due to their smoky, purple-gray aphanitic matrix. In most cases, the term 
"smoked salmon" will be used in this thesis. Burnham (2005) provided additional evidence to correlate the clasts from Point Lobos and Point Reyes, including U-Pb zircon ages of $151.6 \pm 2.6 \mathrm{Ma}$ from these locations.

\section{Paleomagnetic Data}

Paleomagnetic data published by Champion et al. $(1981,1984)$ suggested that the Pigeon Point Formation, generally thought at the time to overlie the Salinian block, was a far-traveled terrane, transported about $2500 \mathrm{~km}$ from a paleolatitude near southern Mexico to its current location. Champion was one of several coauthors on subsequent paleomagnetic research published by Whidden et al. (1998) that indicated that the Salinian block is not a far-traveled terrane, but instead, has experienced only $\sim 6^{\circ}$ of latitudinal of displacement. Whidden et al. (1998) further suggested that the Sur-Obispo terrane, which is located farther outboard of the craton than is Salinia, has been transported northward by up to $22^{\circ}$ since the Late Cretaceous. Substantial northward transport of the Sur-Obispo terrane is also suggested by the paleomagnetic data of Lund et al. (1991). 


\section{METHODS}

\section{Field}

Three methods are commonly employed to count clasts (e.g. Howard, 1983): the grid method, analogous to the thin-section point-count technique in which grains are identified at each intersection of a grid (Williams et al., 1982); the line method, in which all clasts are counted along a stretched line; and the area method, in which all clasts are counted within a specified area.

In her study of the evolution of Late Cretaceous basin formation, Grove (1989) used a grid method and counted clasts generally $1-10 \mathrm{~cm}$ in diameter. In their study of conglomerates related to the place of origin of the Salinian block, Seiders and Cox (1982) selected primarily $0.4-3.0 \mathrm{~cm}$ clasts using an area method. This small clast-size limit was imposed in part to limit locally derived clasts. Tumbling experiments (Abbott and Peterson, 1978) demonstrated that, in an environment consisting of clasts of mixed durability, low durability rocks are eliminated quickly whereas highly durable rocks travel farther and become concentrated with time. The intent of my research is to use clast characterization to limit provenance of igneous clasts in the Pigeon Point Formation, and it would be 
helpful to be able to compare my results with the datasets of both Grove (1989) and Seiders and Cox (1982). However, since the Pigeon Point Formation is generally fault-bounded and on basement of uncertain affinity, locally derived clasts are important to the study, and my results would not be comparable to those of Seiders and Cox (1982). Clasts from distant provenance are also important, because distinctive durable clasts could potentially be correlated to those in other depositional basins or original source terranes.

Accordingly, I selected clasts generally 1-10 cm diameter, and used the grid method in order to build on the dataset of Grove (1989). The major conglomeratic unit of the Pigeon Point Formation is member G of Lowe $(1979,2004)$. This is the key correlative unit used to link the northern and southern sections of the formation (Howell and Joyce, 1981). Grove (1989) sampled member G in the southern section, exposed near the lighthouse at Pigeon Point. I sampled member G in the northern section, located on private land $\sim 1 \mathrm{~km}$ south of Bean Hollow State Beach (Figure 4). 


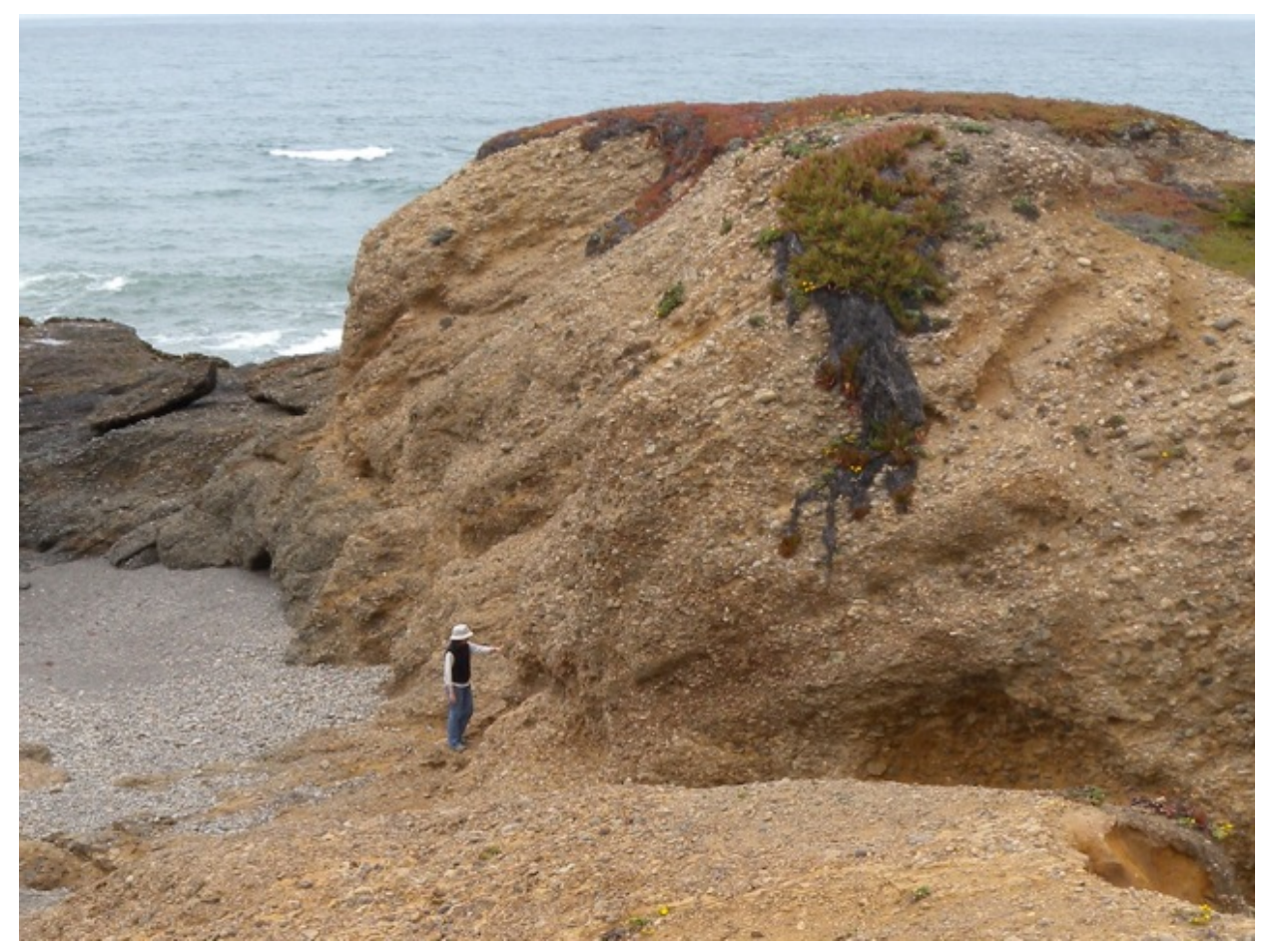

Figure 4. Pigeon Point Formation outcrop photograph. Member G of north section, about $1 \mathrm{~km}$ south of Bean Hollow.

Although Taylor (1988) used a line method to count clasts in the overlying Vaqueros(?) Formation, my thesis required the comparison of clasts between the Pigeon Point and Vaqueros(?) Formations, so a grid method was employed for the Vaqueros(?) Formation as well. For the latter formation, sampling was conducted in the basal conglomerate outcrops located immediately above the unconformable contact with the Pigeon Point Formation at Pescadero State Beach (Figure 5). 


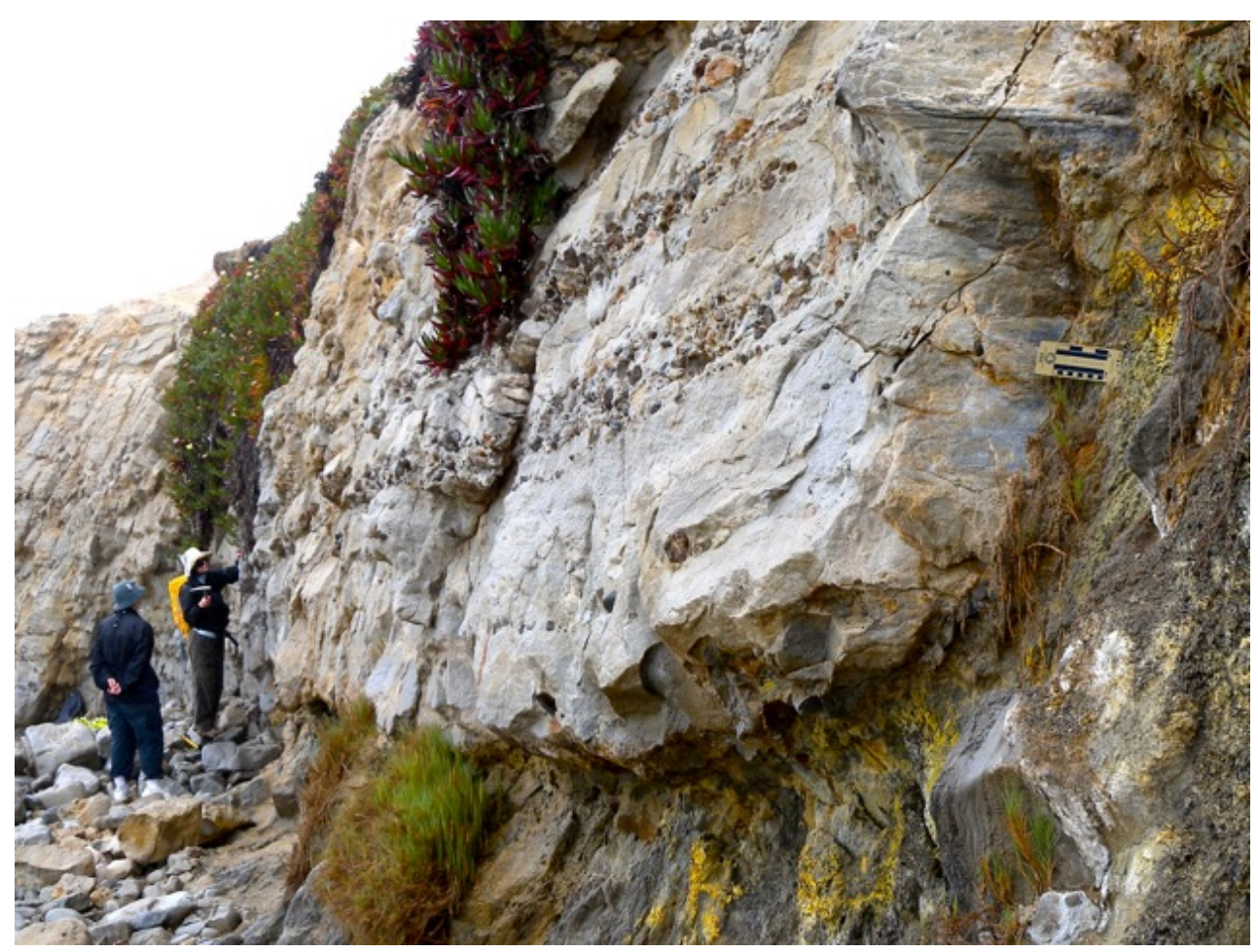

Figure 5. Vaqueros(?) Formation outcrop photograph. Nearly vertical thin-bedded turbidites of the lowest exposed member of the Pigeon Point Formation are overlain in faulted unconformity by sandstone and conglomerate beds of the Vaqueros(?) Formation at Pescadero Beach. Horizontal scale $10 \mathrm{~cm}$ long rests next to slickensided Vaqueros(?) outcrop.

A $100-\mathrm{cm}^{2}$ grid with $10-\mathrm{cm}$ spaces was used, and clasts under the intersections were identified until a count of 100 was reached for each formation. A reconnaissance was done beyond the gridded areas for any additional clasts types that may not have been included in the systematic sampling, including the large angular boulders seasonally exposed at the base of the Vaqueros(?) Formation.

Clasts matching the description of the underlying Pescadero felsite of Ernst et al. (2009) were identified in the Pigeon Point Formation. Thus, for further 
comparison, samples were subsequently taken of the massive Pescadero felsite at the outcrop just west of the town of Pescadero and in the adjacent zone of sheared metaconglomerate (Figure 2). Clasts matching the description of both the "smoked salmon" of Bachman and Abbott (1988) and "purple porphyry" of Burnham (2005) were also identified, so for further comparison, this clast type was sampled from the Carmelo Formation at Point Lobos (Figure 1).

Additional observations were made along the beach (Figure 2) in order to understand the nature of the key contacts and faults within and between the Pigeon Point and Vaqueros(?) Formations. Conglomerates exposed near the intersection of Pescadero and Bean Hollow Roads were also studied in order to determine their affinity with the aforementioned beach exposures of conglomeratic lenses within the Pigeon Point Formation.

\section{Laboratory}

Thin sections of over 100 clasts were made, two per sample. One set was stained to aid in feldspar identification, and the other set was processed uncovered, for possible microprobe work. The thin sections were analyzed for phenocryst mineralogy, mineral assemblages indicative of degree of metamorphism, and textural properties. The thin sections were specifically examined for evidence of 
low-temperature burial metamorphism, as observed in the Pescadero felsite (Ernst et al., 2009).

Whole rock XRF and ICP-MS geochemical analyses of both the Pescadero felsite and "smoked salmon" clasts were done at the Washington State University GeoAnalytical Lab to obtain major, trace, and rare-earth data. Detailed description of methods, precision, and accuracy can be found at http://www.sees.wsu.edu/Geolab/note.html (Johnson et al., 1999)

\section{PETROGRAPHIC OBSERVATIONS}

\section{Pigeon Point Formation}

Table 2 lists conglomeratic clast counts for the Pigeon Point Formation. The dominant clast type is felsic volcanic, comprising an estimated $47 \%$ of the clast population. It typically presents as a small (average $\sim 6 \mathrm{~cm}$ diameter), very hard, rounded rock, commonly with feldspar phenocrysts in a dark aphanitic matrix. Many are tuffs, with various degrees of flow textures in the matrix . 
Table 2. Clast counts.

\begin{tabular}{|c|c|c|c|c|}
\hline & \multicolumn{2}{|c|}{$\begin{array}{l}\text { Pigeon Point Formation } \\
\text { Member G, north section }\end{array}$} & \multicolumn{2}{|c|}{$\begin{array}{l}\text { Vaqueros(?) Formation } \\
\text { Basal conglomerate }\end{array}$} \\
\hline & Count $(n=100)$ & Mean diameter & Count $(n=100)$ & Mean diameter \\
\hline Felsic Volcanic & 47 & $6 \mathrm{~cm}$ & 43 & $4 \mathrm{~cm}$ \\
\hline $\begin{array}{l}\text { Intermediate } \\
\text { Volcanic }\end{array}$ & 25 & $5 \mathrm{~cm}$ & 5 & $3 \mathrm{~cm}$ \\
\hline Plutonic & 16 & $10 \mathrm{~cm}$ & 28 & $6 \mathrm{~cm}$ \\
\hline Quartzite & 5 & $5 \mathrm{~cm}$ & 18 & $6 \mathrm{~cm}$ \\
\hline $\begin{array}{l}\text { Sedimentary, } \\
\text { Other }\end{array}$ & 7 & - & 6 & - \\
\hline
\end{tabular}

The next most abundant clast, comprising about $25 \%$ of the population, is an intermediate volcanic rock (Figures 6A, 6B). These clasts are also rather small (average $\sim 5 \mathrm{~cm}$ diameter) and commonly have fewer phenocrysts than do the silicic clasts. In thin section, a felty network of plagioclase laths is observed in some of the intermediate clasts.

Plutonic clasts comprise about $16 \%$ of the population. These are typically much larger than the volcanic clasts, averaging about $10 \mathrm{~cm}$. Most of the plutonic clasts are tonalites, rich in plagioclase feldspar and quartz, with potassium feldspar almost non-existent (Figure 6C). A few are diorites, with dominantly plagioclase feldspar plus amphibole and a lesser amount of quartz. 

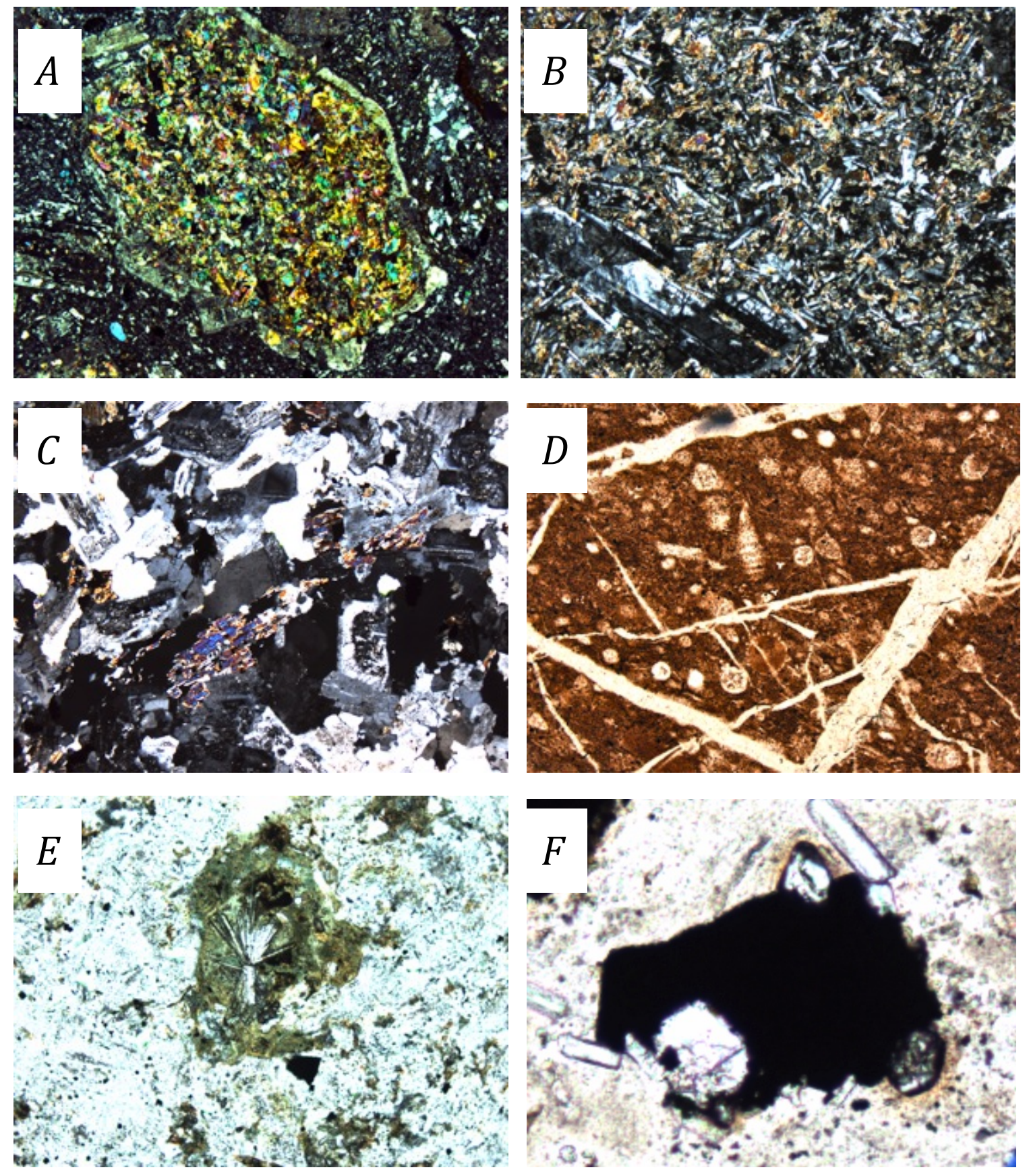

Figure 6. Photomicrographs, Pigeon Point. $A$. Intermediate volcanic clast; plagioclase phenocryst replaced by epidote. XP, $3.5 \mathrm{~mm}$. $B$. Intermediate volcanic with intersertal matrix of plagioclase laths. XP, $3.5 \mathrm{~mm}$. $C$. Fine-grained plutonic clast includes actinolite, anhedral quartz, zoned plagioclase. XP, $3.5 \mathrm{~mm}$. D. Radiolarian chert. PL, $1.5 \mathrm{~mm}$. E. Pescadero felsite clast, bow-tie prism of prehnite in center. PL, $3.5 \mathrm{~mm}$. F. "Smoked salmon" felsic volcanic clast; zircons and apatite cluster near opaques. PL, $0.5 \mathrm{~mm}$. XP: cross-polarized. PP: plane-polarized. Field of view in $\mathrm{mm}$. 
About $7 \%$ of the clasts are a variety of sedimentary and other rocks, including mudstone, siltstone, and $<1 \%$ red and green chert. The red chert is rich in radiolarians (Figure 6D). Quartzite is also present, comprising about 5\% of the clasts, and is typically small, averaging about 4-5 $\mathrm{cm}$ in diameter.

These conglomeratic clast findings are consistent with those reported by Grove (1989) for member G of the southern section, located near the Pigeon Point lighthouse (Figure 2).

Included in the felsic volcanic rocks are a few ( 5\%) medium-gray, porphyritic clasts that contain abundant glomerophyric plagioclase laths in a matrix with radial spherulitic arrangements of crystals. These clasts include pumpellyite and rare prehnite (Figure 6E), which is otherwise absent in clasts of the Pigeon Point Formation, but present in the underlying Pescadero felsite (Ernst et al., 2009; Sanquini et al., 2010).

Also included in the felsic volcanic rocks is a dark volcanic porphyry, comprising $<1 \%$ of the population, which contains about $25 \%$ subhedral to euhedral salmon-pink potassium feldspar phenocrysts, averaging about $2 \mathrm{~mm}$ in length and commonly exhibiting perthitic texture. Zircons clustering on opaques were observed (Figure 6F), described by Burnham (2005) as characteristic of the "purple porphyry" clasts found in abundance at Point Lobos and Point Reyes. Some of the clasts contain heavily embayed quartz phenocrysts, and varying amounts of 
flow texture in the matrix. They match in hand sample and in thin section the descriptions of both the "smoked salmon" clasts of Bachman and Abbott (1988) and the "purple porphyry" clasts of Burnham (2005). They also match "smoked salmon" clasts collected and thin sectioned for this thesis from the Carmelo Formation at Point Lobos (Figure 1).

\section{Vaqueros(?) Formation}

The basal conglomerate unit of the Vaqueros(?) Formation includes about $43 \%$ felsic volcanic clasts, $28 \%$ fine-grained plutonic clasts, and $18 \%$ quartzite clasts (Table 2). This count is generally consistent with the findings of Taylor (1988), if the Taylor count of $19 \%$ metamorphic clasts is interpreted, as is suggested in his text, as comprised primarily of quartzite. In addition, I identified a small number of intermediate volcanic clasts $(\sim 5 \%)$, whereas Taylor listed none.

Two distinctly different plutonic clasts are present in the Vaqueros(?) Formation. The fine-grained plutonic clasts mentioned above are granites. They include about 5-10\% plagioclase feldspar, 30-40\% quartz, and $40-50 \%$ potassium feldspar. Recrystallized quartz and myrmekite texture are common (Figures 7A, 7B). In contrast, the angular, medium- to coarse-grained plutonic boulders present at the very base of the Vaqueros(?) formation are granodiorite (Figure 7C). These 
rocks have abundant ( $\sim 50 \%$ ) plagioclase feldspar crystals, plus about 30\% quartz, $12 \%$ potassium feldspar, and $10 \%$ biotite mica; hornblende was not observed.

A variety of felsic volcanic clasts are present. Potassium feldspars in these rocks are often perthitic (Figure 7D). Glassy, flowing matrix is locally well developed and perlitic cracking is present in many samples (Figure 7E). A mediumgray clast with small plagioclase phenocrysts and a spherulitic texture resembling that of the Pescadero felsite was noted (Figure 7F), but thin section examination revealed a lack of the characteristic low-grade metamorphic prehnite-pumpellyite mineral assemblage, so the clast is not correlated with the Pescadero felsite. 

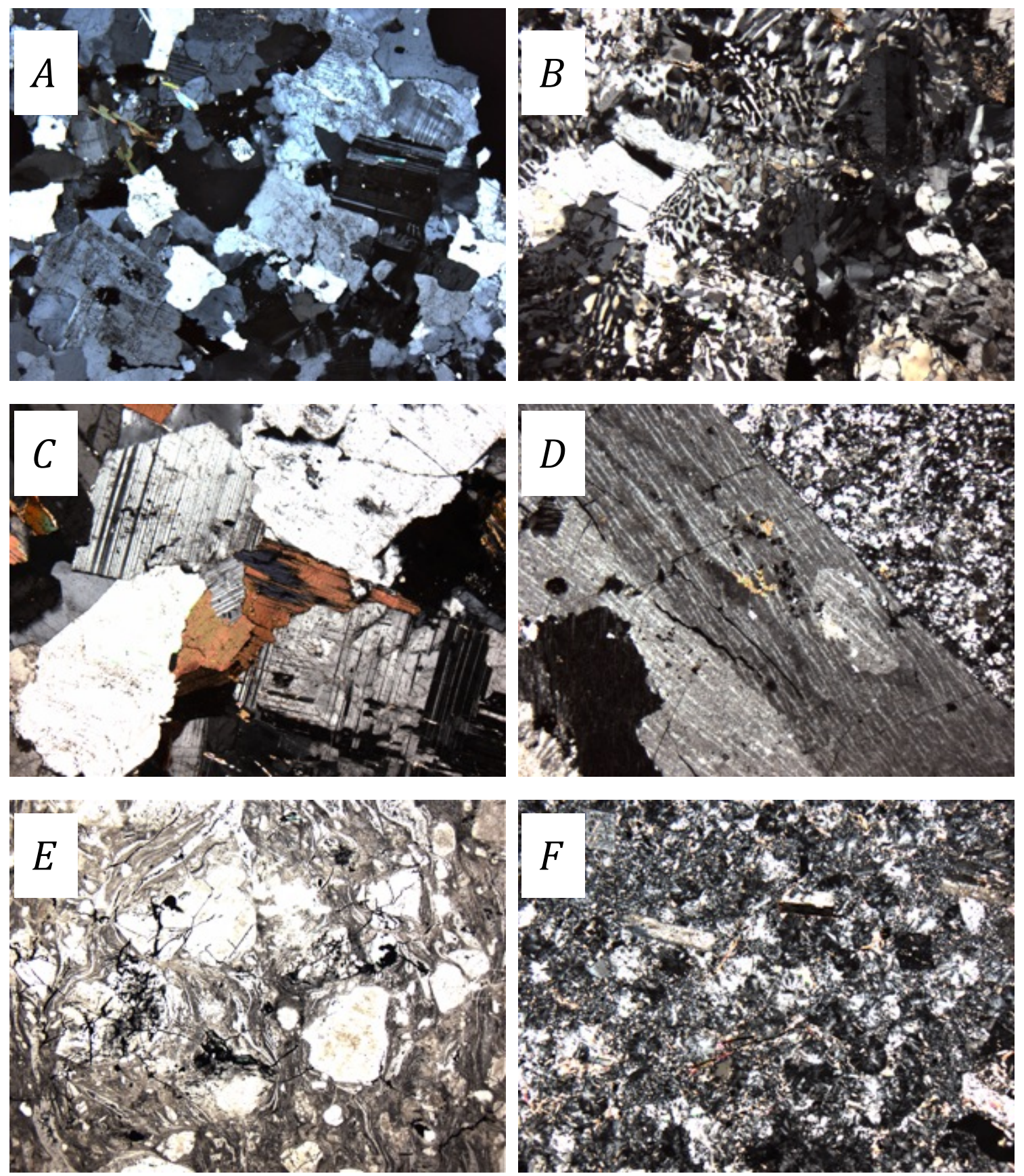

Figure 7. Photomicrographs, Vaqueros(?). A. Fine-grained plutonic clast; quartz is recrystallized. Plagioclase and microcline to the right. . XP, $3.5 \mathrm{~mm}$. B. Myrmekite texture in a fine-grained plutonic clast. XP, $3.5 \mathrm{~mm}$. C. Coarse-grained granodiorite clast with plagioclase, biotite, K-spar, and quartz. XP, $3.5 \mathrm{~mm}$. D. Perthitic K-spar phenocryst in a felsic volcanic clast. XP, $3.5 \mathrm{~mm}$. E. Felsic volcanic clast with glassy matrix and perlitic texture. PP, $7 \mathrm{~mm}$. F. Felsic volcanic clast, spherulitic texture. XP, $3.5 \mathrm{~mm}$. XP: cross-polarized. PP: plane-polarized. Field of view in $\mathrm{mm}$. 


\section{MAJOR AND TRACE ELEMENT CHEMISTRY}

\section{Pescadero Felsite Samples}

Major and trace element analyses of the Pescadero felsite samples are listed in the first three columns of Table 3. Major oxide analyses for the felsite samples are similar, with the exception of relatively low $\mathrm{Al}_{2} \mathrm{O}_{3}$ and high $\mathrm{CaO}$ in the clast from the shear zone between the underlying massive Pescadero felsite and the overlying Pigeon Point Formation. This chemical variation may reflect significant alteration within the shear zone. There is some divergence in the large ion lithophile elements (LILs), notably barium. For these elements, the massive Pescadero felsite sample is somewhat to significantly depleted relative to other samples. As explained by Rollingson (1993), the LILs are mobile elements, and affected by hydrothermal alteration or low-grade metamorphism. The variation in the LILs may be due to variation in the extent of alteration of the Pescadero felsite samples from the three different locations. In contrast to the LILs, the REE patterns of the Pescadero felsite samples are remarkably consistent (Table 3 and Figure 8). All three samples are enriched relative to chondrite in both light and heavy REEs, with an overall flat trend, and a small negative Eu anomaly. 


\begin{tabular}{|c|c|c|c|c|c|}
\hline \multirow[b]{2}{*}{ Location: } & \multicolumn{3}{|c|}{ Pescadero Felsite } & \multicolumn{2}{|c|}{ Smoked Salmon } \\
\hline & Pigeon Pt. & Pesc Shear & Pesc Massive & Pigeon Pt. & Pt.Lobos \\
\hline Sample: & B61 & PP309 & PP4-4-8 & B8 & 54 \\
\hline \multicolumn{6}{|l|}{ wt $8^{\prime}$} \\
\hline SiO2 & 71.95 & 75.82 & 76.75 & 74.36 & 75.32 \\
\hline TiO2 & 0.404 & 0.249 & 0.307 & 0.228 & 0.241 \\
\hline A1203 & 12.53 & 7.90 & 10.81 & 13.50 & 12.98 \\
\hline $\mathrm{FeO} *$ & 4.43 & 2.30 & 1.81 & 0.61 & 1.28 \\
\hline Mno & 0.054 & 0.065 & 0.040 & 0.007 & 0.011 \\
\hline Mgo & 1.29 & 0.83 & 0.26 & 0.12 & 0.11 \\
\hline $\mathrm{CaO}$ & 1.38 & 4.79 & 2.06 & 0.24 & 0.11 \\
\hline $\mathrm{Na2O}$ & 5.09 & 3.02 & 5.98 & 3.45 & 4.72 \\
\hline $\mathrm{K} 2 \mathrm{O}$ & 0.79 & 0.53 & 0.04 & 5.79 & 4.40 \\
\hline P205 & 0.098 & 0.052 & 0.058 & 0.044 & 0.034 \\
\hline Sum & 98.02 & 95.56 & 98.12 & 98.35 & 99.19 \\
\hline \multicolumn{6}{|l|}{ ppm } \\
\hline La & 5.00 & 4.12 & 4.40 & 22.45 & 22.72 \\
\hline $\mathrm{Ce}$ & 9.88 & 9.25 & 10.44 & 45.91 & 43.58 \\
\hline Pr & 1.73 & 1.52 & 1.71 & 3.75 & 6.38 \\
\hline Nd & 8.12 & 7.22 & 8.43 & 13.09 & 23.05 \\
\hline $\mathrm{Sm}$ & 2.64 & 2.23 & 2.71 & 2.46 & 4.68 \\
\hline Eu & 0.80 & 0.58 & 0.65 & 0.52 & 0.72 \\
\hline Gd & 3.28 & 2.85 & 3.56 & 2.32 & 4.23 \\
\hline $\mathrm{Tb}$ & 0.63 & 0.53 & 0.66 & 0.47 & 0.88 \\
\hline Dy & 4.30 & 3.49 & 4.48 & 3.64 & 6.41 \\
\hline Hо & 0.96 & 0.79 & 1.00 & 0.89 & 1.48 \\
\hline Er & 2.84 & 2.32 & 2.90 & 2.91 & 4.62 \\
\hline $\mathrm{Tm}$ & 0.45 & 0.35 & 0.44 & 0.49 & 0.73 \\
\hline $\mathrm{Yb}$ & 2.91 & 2.28 & 2.82 & 3.29 & 4.77 \\
\hline Lu & 0.47 & 0.38 & 0.47 & 0.55 & 0.77 \\
\hline $\mathrm{Ba}^{\prime}$ & 237.00 & 134.00 & 11.00 & 473.00 & 305.00 \\
\hline Th & 0.99 & 0.74 & 0.90 & 25.87 & 16.47 \\
\hline $\mathrm{Nb}$ & 1.21 & 0.94 & 1.07 & 16.84 & 20.29 \\
\hline $\mathrm{Y}$ & 23.80 & 21.18 & 26.76 & 23.76 & 39.75 \\
\hline Hf & 2.24 & 1.98 & 2.47 & 6.00 & 8.27 \\
\hline $\mathrm{Ta}$ & 0.09 & 0.07 & 0.08 & 1.21 & 1.36 \\
\hline $\mathrm{U}$ & 0.51 & 0.28 & 0.36 & 4.58 & 2.93 \\
\hline $\mathrm{Pb}$ & 2.80 & 2.42 & 1.75 & 17.06 & 13.02 \\
\hline $\mathbf{R b}^{\prime}$ & 9.00 & 6.00 & 0.00 & 204.00 & 136.00 \\
\hline $\mathrm{Cs}$ & 0.87 & 0.12 & 0.02 & 4.44 & 0.77 \\
\hline$s x^{1}$ & 111.00 & 65.00 & 33.00 & 94.00 & 41.00 \\
\hline sc & 16.93 & 10.28 & 10.90 & 5.73 & 4.88 \\
\hline $2 r^{\prime}$ & 67.00 & 59.00 & 77.00 & 189.00 & 290.00 \\
\hline
\end{tabular}

*Total Fe Expressed as FeO. ${ }^{1}$ These analyses were done by XRF, all others by ICP-MS. 


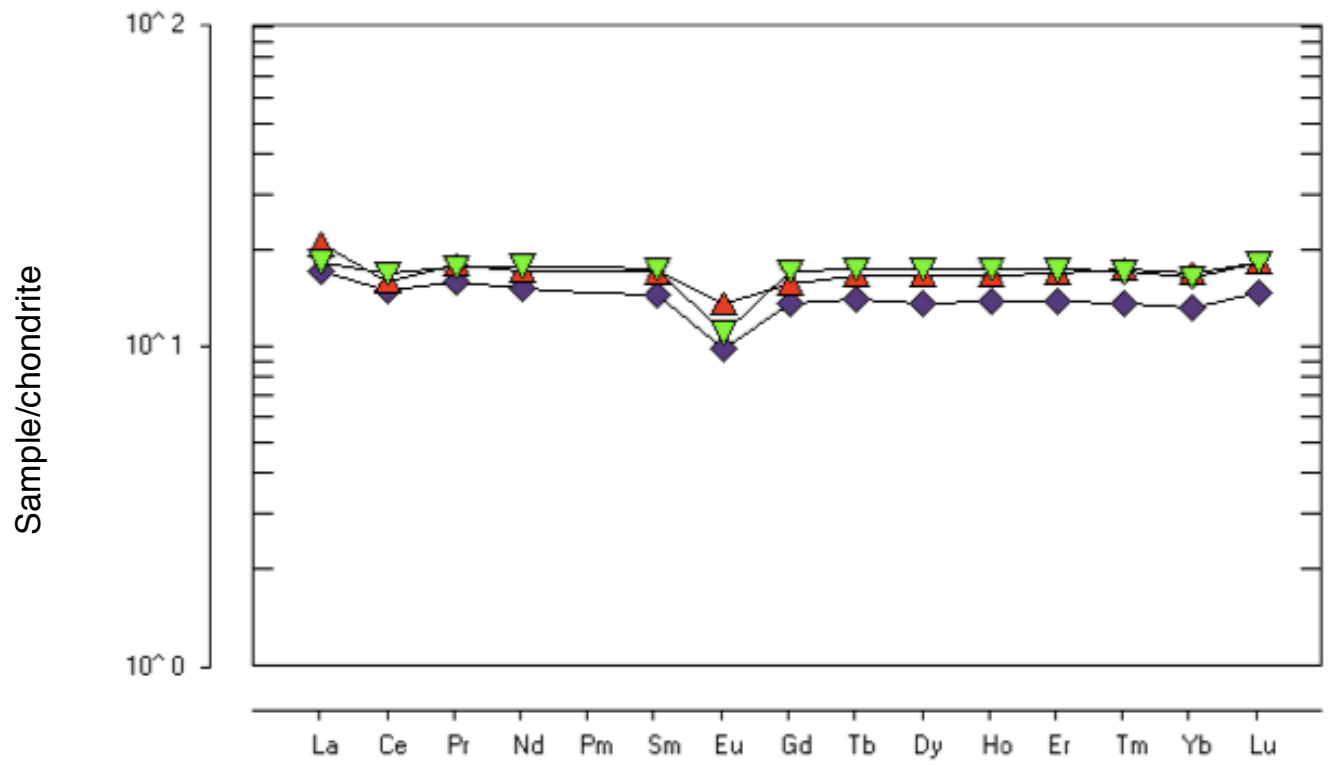

Figure 8. REE diagram of Pescadero felsite samples. Clast from Pigeon Point Formation (up-pointed triangle), clast from sheared metaconglomerate (diamond) and sample from massive Pescadero felsite (down-pointed triangle). Analyses done by ICP-MS. Chondrite normalization values are from Sun and McDonough (1989).

The amount of iron present (Table 3) suggests that the Pescadero felsite was originally less silicic than it is now. It may have initially been a dacite that was subsequently albitized, gaining silica in the process. To help constrain provenance of this material, a tectonic discrimination analysis was applied that only used relatively stable trace elements, since the Pescadero felsite has been altered. Due to uncertain composition of original material, the Th-Hf/3-Ta diagram (Figure 9) was chosen for this purpose, as it can be applied to silicic, intermediate, and mafic lavas (Rollingson, 1993). The Pescadero felsite plots within the field of calc-alkaline flows, near the boundary with island-arc tholeiites. 


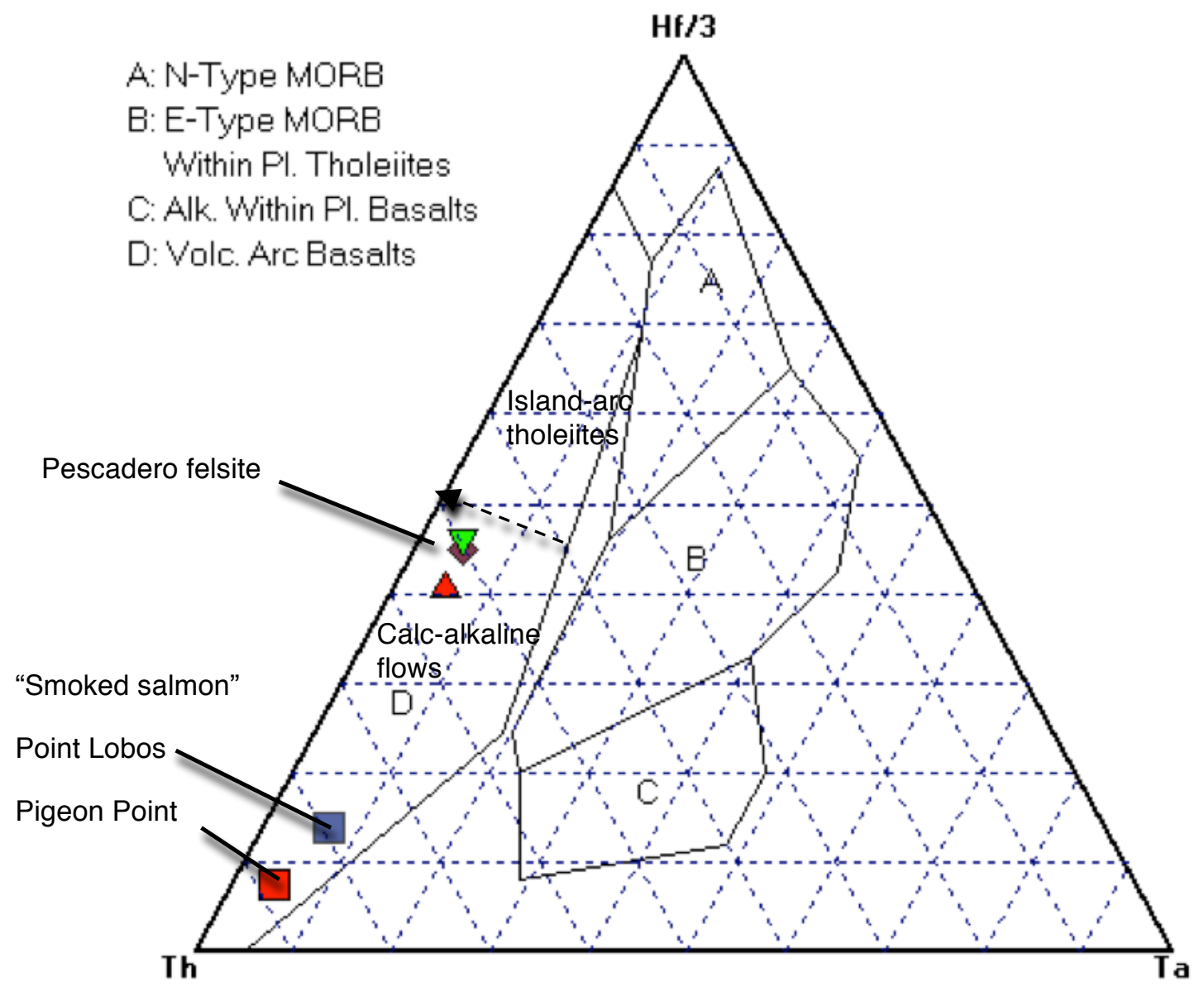

Figure 9. Th-Hf/3-Ta tectonic discrimination diagram. (Wood, 1980). Pescadero felsite symbols are the same as in Figure 8.

\section{“Smoked Salmon” Clasts}

Major oxides and trace element analyses for "smoked salmon" clasts from the Pigeon Point Formation and from the Carmelo Formation at Point Lobos are listed in the last two columns of Table 3. Oxides from the Bachman and Abbott (1988) 
samples from Point Lobos, Point Reyes, Adelaida Ranch, and Garcia Mountain overlap. The authors interpreted this as supportive of their hypothesis that these distinctive clasts are all from the same source. Major oxides from the "smoked salmon" clast from the conglomerate of the Pigeon Point Formation fit in well with the overlapping Bachman and Abbott (1988) data.

The REE compositions of the clasts reveal significant enrichment of the light REEs, a somewhat enriched but relatively flat trend of the heavy REEs, and a modest negative Eu anomaly (Figure 10).

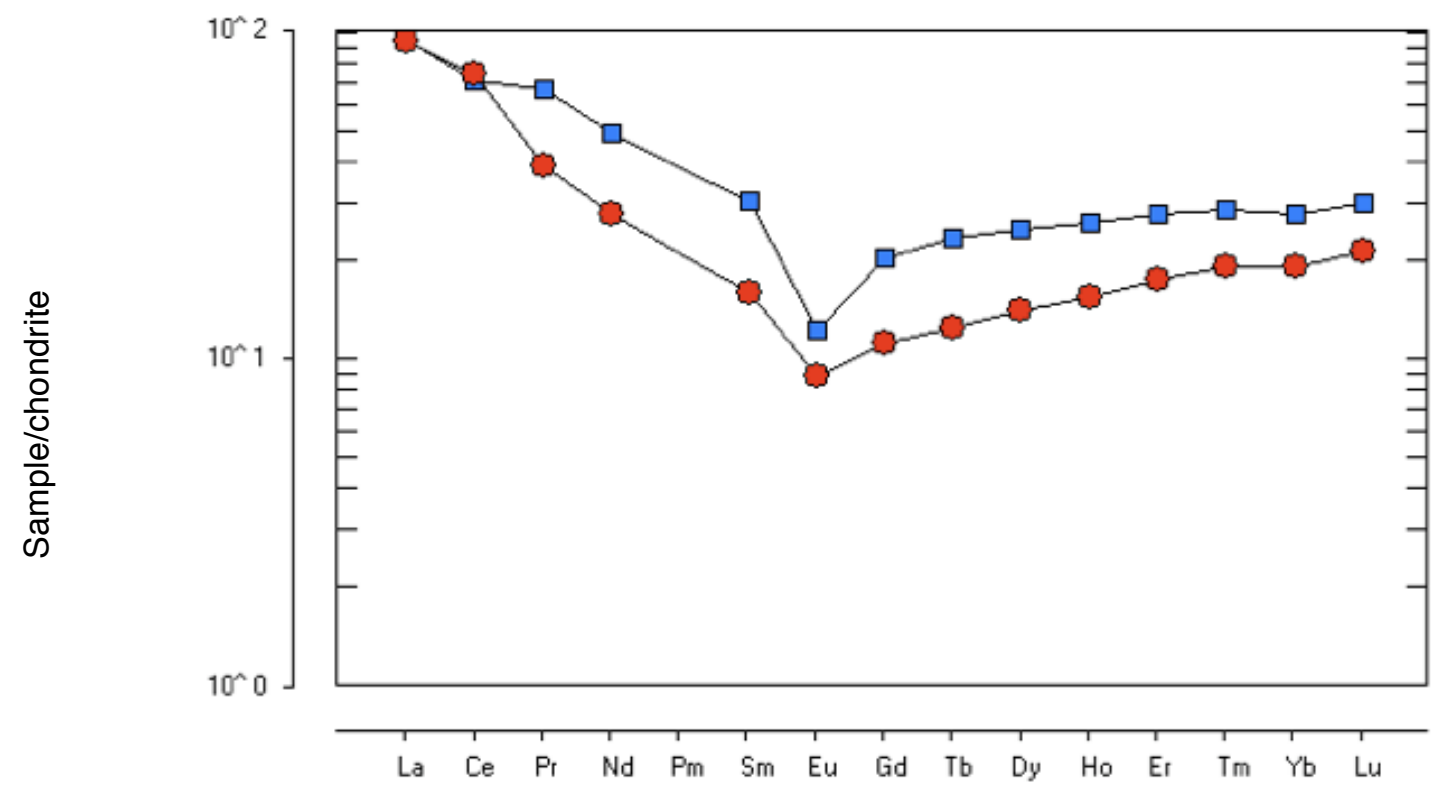

Figure 10. REE diagram of "smoked salmon" samples. Clast from Pigeon Point Formation (circle), clast from Point Lobos Carmelo Formation (square). Analyses done by ICP-MS. Chondrite normalization values are from Sun and McDonough (1989). 
This is a somewhat unusual pattern, as most Andean arc-type rhyolites exhibit a continued decreasing slope. The large "tipping gull wing" profile common to both suggests, along with the major oxide and the petrographic data, that the "smoked salmon" clasts are from the same source. On the Th-Hf/3-Ta diagram (Figure 9), the clasts plot low within the field of calc-alkaline flows.

\section{INTERPRETATION OF DATA}

\section{Age of Pigeon Point Conglomerate and Timing of Key Events}

\section{Conglomerate Age Analysis}

Table 4 lists detrital zircon (Jacobson et al., 2010) and molluscan assemblage (Elder and Saul, 1993) ages for the Pigeon Point Formation. The clasts from the conglomeratic member G, northern section (Lowe, 2004) are a primary data source for this thesis, so ascertaining the depositional age of that unit provides important context to subsequent interpretation of findings from it. Since a conglomerate bed may lack fossils suitable for dating, its age may be inferred from the ages of units located stratigraphically above and below the bed in question. 
Table 4. Age controls on Pigeon Point Formation. See Figure 1 for locations. Data not available indicated by $n / a$.

\begin{tabular}{|l|l|l|}
\hline $\begin{array}{l}\text { Pigeon Point Formation } \\
\text { member, beach outcrops } \\
\text { Lowe, 1979 and 2004) }\end{array}$ & $\begin{array}{l}\text { Molluscan assemblage } \\
\text { inferred age (Elder and } \\
\text { Saul, 1993 unless } \\
\text { otherwise noted) }\end{array}$ & $\begin{array}{l}\text { Youngest U-Pb detrital } \\
\text { zircon age (Jacobson et al., } \\
\text { 2010) }\end{array}$ \\
\hline Member I & Mid-Campanian & n/a \\
\hline Member H & Early-mid Campanian & $92 \pm 6 \mathrm{Ma}(80 \pm 5 \mathrm{Ma})^{1}$ \\
\hline Member G (Conglomerate) & n/a & n/a \\
\hline Member F & Mid-late Campanian & n/a \\
\hline Member E & n/a & n/a \\
\hline Member D & $\begin{array}{l}\text { Maastrichtian - late } \\
\text { Campanian (Hall et al., } \\
1959)\end{array}$ & $95 \pm 2 \mathrm{Ma}$ \\
\hline Member C & n/a & n/a \\
\hline Member B & n/a & n/a \\
\hline Member A & Early Campanian & Ma (73 $\pm 4 \mathrm{Ma})^{1}$ \\
\hline
\end{tabular}

${ }^{1}$ Earlier age interpreted by Jacobson et al. (2010) as possibly anomalous.

A mid-late Campanian age has been suggested by Elder and Saul (1993) for member $\mathrm{F}$ in the northern sequence, located immediately below the conglomeratic member G (Figures 2 and 3). The two members are in depositional contact and although minor faulting pervades the overall formation, there are no major fault separations between members F and G. From this, it is inferred that the member G exposed in the northern section is no older than mid-late Campanian ( 70-77 Ma). As depicted in Figure 2, the northern section is faulted immediately above member G, and neither fossils nor zircons were dated in any stratigraphically higher units in the northern section, so an upper age limit for the conglomerate cannot be directly determined. 
In the southern section, conglomerate member $\mathrm{G}$ is in depositional contact with member $\mathrm{H}$, from which molluscan assemblage ages of early-mid Campanian ( 77-83 Ma) were obtained, and the youngest detrital zircon age is $\sim 80 \mathrm{Ma}$. The conglomerate unit of the southern section was tentatively correlated with the unit exposed in the northern section by Howell and Joyce (1981). The clast analysis done for this thesis is in good agreement with the work done by Grove (1989) on member $\mathrm{G}$ of the southern section and further supports the Howell and Joyce (1981) correlation. Thus, the age controls from member $\mathrm{H}$ of the southern section can be used to infer an upper limit on the age of the northern section conglomerate member G.

Based on ages of stratigraphically higher and lower units, the conglomeratic member $\mathrm{G}$ of the northern sequence was likely deposited during the midCampanian.

\section{Key Events}

Table 5 summarizes my results and those of previous workers to reconstruct the key events that affected the study area from just prior to deposition of the Pigeon Point Formation until the present. 
Table 5. Timing of key events. All dates are approximate. References given in text.

\begin{tabular}{|c|c|}
\hline Absolute and/or relative date & \\
\hline 90 to $\sim 86 \mathrm{Ma}$ & $\begin{array}{l}\text { Pescadero felsite (calc-alkaline to borderline island arc } \\
\text { tholeiite, } \sim \text { flat REE) erupted into accretionary complex. }\end{array}$ \\
\hline 86 to $\sim 80 \mathrm{Ma}$ & $\begin{array}{l}\text { Pescadero felsite buried to prehnite-pumpellyite facies; } \\
\text { uplifted and eroded. }\end{array}$ \\
\hline $\begin{array}{l}80 \text { to } \sim 70 \mathrm{Ma} \\
\text { mid Campanian }\end{array}$ & $\begin{array}{l}\text { Marine Pigeon Point Fm deposited atop Pescadero } \\
\text { felsite in warm-temperate to subtropical climate. Clasts } \\
\text { include: } \\
\text { * underlying Pescadero felsite } \\
\text { * red radiolarian chert } \\
\text { * "smoked salmon" from inland source } \\
\text { * tonalite with initial }{ }^{87} \mathrm{Sr} /{ }^{86} \mathrm{Sr}=0.70468 \text { to } 0.70571\end{array}$ \\
\hline$\sim$ Paleogene & $\begin{array}{l}\text { * Slip on Nacimiento fault truncates } \sim 150 \mathrm{~km} \text { of great } \\
\text { valley and western Sierran arc material. } \\
\text { * Farallon plate flat slab subduction, Laramide orogeny, } \\
\text { uplift to east }\end{array}$ \\
\hline$\sim 27 \mathrm{Ma}$ & $\begin{array}{l}\text { Pacific plate approaches North American plate, margin } \\
\text { changes from compression to transtension }\end{array}$ \\
\hline $\begin{array}{l}\sim 22 \mathrm{Ma} \\
\text { Miocene }\end{array}$ & $\begin{array}{l}\text { Marine Vaqueros(?) Formation deposited onto eroded, } \\
\text { folded and faulted Pigeon Point Formation. Includes } \\
\text { interbedded basalt flows. Initial }{ }^{87} \mathrm{Sr} /{ }^{86} \mathrm{Sr} \text { of granodiorite } \\
\text { and granite clasts: } 0.70599 \text { to } 0.71200 \text {. }\end{array}$ \\
\hline $\begin{array}{l}\sim 10 \text { to } 0 \mathrm{Ma} \\
\text { late Miocene to present }\end{array}$ & $\sim 150-160 \mathrm{~km}$ dextral slip on San Gregorio-Hosgri fault. \\
\hline
\end{tabular}

\section{Linkage to Underlying Unit}

About 5 percent of the clasts in the $\sim 77$ Ma conglomeratic member G, northern section (Lowe, 1979, 2004) of the Pigeon Point Formation are a match with the underlying 86-90 Ma Pescadero felsite. Field observations of the 
structure and composition of the conglomerate and minor sandstone beds exposed near the felsite outcrop suggest that this unit is also member G (Figures 2 and 3). The depositional relationship depicted in stratigraphic column 3, Figure 3, suggest an incised upper submarine canyon placed the conglomerate unit in almost direct contact with the underlying Pescadero felsite. Between the two units is a zone of sheared metaconglomerate (Ernst et al., in press), so fault slip may also have contributed to the stratigraphic relationship of the Pigeon Point Formation conglomeratic member G and the Pescadero felsite.

Common characteristics between the Pescadero felsite samples and correlative clasts from the Pigeon Point Formation include similar texture, composition (Table 3), REE patterns (Figure 8) and the presence of pumpellyite \pm prehnite, indicative of low-temperature burial metamorphism. This metamorphic assemblage is otherwise absent in clasts of the Pigeon Point Formation, suggesting that the Pescadero felsite is the source of the felsitic conglomerate clasts and the Pescadero felsite was buried to prehnite-pumpellyite facies conditions, exhumed, and eroded prior to or during the deposition of the Pigeon Point Formation (Ernst et al., 2009; Sanquini et al., 2010).

The Pescadero felsite is characterized as calc-alkaline, bordering on island arc tholeiitic (Figure 9). Ernst et al. (in press) suggested that the Pescadero felsite magma formed in part by anatexis of clastic Franciscan or Great Valley affinity 
strata. Consistency with the chemical analysis requires that the partially melted clastic sediments are of fairly primitive composition.

Chemical analysis suggests that source magma for the "smoked salmon" clasts in the Pigeon Point Formation is different from that of the Pescadero felsite. If they are correlative with the $\sim 152$ Ma clasts from Point Lobos and Point Reyes (Burnham, 2005), they are $\sim 60$ m.y. older than the Pescadero felsite, and likely transported to the area of deposition from a distal source.

\section{Comparison to Overlying Unit}

The contact between the Late Cretaceous Pigeon Point Formation and the late Oligocene-early Miocene Vaqueros(?) Formation represents a gap of 50 m.y., indicating non-deposition or erosion prior to deposition of the overlying unit (Taylor, 1988; Dunkel, 1997).

The Pigeon Point and Vaqueros(?) formations both are marine conglomerates and contain abundant silicic volcanic clasts. However, they differ in significant ways. The mean P/F ratio of the Vaqueros(?) Formation sandstone is 0.52 but the plagioclase-rich Pigeon Point Formation mean P/F ratio is 0.73 . The Vaqueros(?) formation includes $\sim 20 \%$ quartzite clasts, whereas quartzites in the Pigeon Point Formation are relatively rare. Granitoid clasts of the Pigeon Point 
Formation are potassium feldspar-poor, and initial strontium isotope ratios are indicative of a transitional oceanic to continental affinity. Angular granodiorite boulders at the base of the Vaqueros(?) Formation are somewhat more evolved, and rounded granite clasts stratigraphically higher in the formation are further evolved, with initial strontium isotope ratios up to 0.71200 (Table 9). The uppermost unit of the Vaqueros(?) Formation includes a variety of $\sim 22$ Ma basaltic rocks, including some interbedded with sandstones. These are not seen in the limited outcrops of the Pigeon Point Formation.

\section{Comparison to Upper Cretaceous Atascadero Formation}

The Pigeon Point Formation has been correlated with the Upper Cretaceous Atascadero Formation east of the San Gregorio-Hosgri fault near San Luis Obispo (Dickinson et al., 2005), but this correlation appears untenable for several reasons.

\section{Paleontology and Inferred Paleolatitudes}

The Pigeon Point Formation and the Atascadero Formation both lie west of the Nacimiento fault, but paleontologic and geologic data do not support their deposition in the same area. The Atascadero Formation has six species of mollusks in common with those identified in the Pigeon Point Formation (Elder and Saul, 1993), but these are primarily the North Pacific climate mollusks. None of the 
mollusca identified at Atascadero suggest tropical conditions (LouElla Saul, written comm., 2010). The Pigeon Point Formation includes a few tropical fossils and was interpreted by Elder and Saul as deposited in a warm-temperate to subtropical climate.

\section{Underlying Rocks Differ}

The rock unit beneath the Atascadero Formation is different from the one beneath the Pigeon Point Formation. The Pescadero felsite, established as underlying the Pigeon Point Formation (Ernst et al., 2009; Sanquini et al., 2010), has not been observed at Atascadero. The Toro Formation, which underlies the Atascadero Formation (Hart, 1976) is not observed at Pigeon Point, either in onshore or offshore areas (Dunkel, 1997). This could be attributed to erosion and removal of the underlying units prior to the deposition of the Late Cretaceous formations, as the depositional relations and metamorphism of the pre-Pigeon Point Formation rocks near Pigeon Point indicate considerable uplift and unroofing of the felsite prior to Pigeon Point deposition (Ernst et al., 2009).

\section{Overlying Rocks Differ}

Dickinson et al. (2005) supported their postulated Atascadero-Pigeon Point correlation by linking the Miocene Cambria Felsite, which overlies the Atascadero Formation, with the Pescadero felsite. However, U-Pb zircon work by Ernst et al. (2009) demonstrated that the Pescadero felsite is Late Cretaceous, and probably 
underlies the Pigeon Point Formation. This finding negates the Cambria FelsitePescadero felsite correlation and its possible support of the Atascadero-Pigeon Point correlation.

Dickinson et al. (2005) also supported the Atascadero-Pigeon Point correlation by correlating the Morro Rock-Islay Hill complex $(22.7 \pm 0.9$ Ma to $28.0 \pm$ 1.0 Ma) northwest of San Luis Obispo (Ernst and Hall, 1974; Cole and Stanley, 1998) with the $22.0 \pm 0.7 \mathrm{Ma}(\mathrm{K}-\mathrm{Ar}$ ) basalt in the Vaqueros(?) Formation (Taylor, 1990). However, volcanic rocks of the Morro Rock-Islay Hill complex are dacite, and those of the Vaqueros(?) Formation are basalt. In addition, an older date of 27-26.5 Ma has been proposed as a more reliable estimate for the Morro Rock-Islay Hill complex (Stanley et al., 2000; Wilson et al., 2005), negating its correlation with the younger (22 $\pm 0.7 \mathrm{Ma}$ ) volcanic rocks of the Vaqueros(?) Formation.

\section{Depositional Locations of the "Smoked Salmon" Clasts}

The Pigeon Point Formation includes rare "smoked salmon" clasts identified at only four other basins in California: Point Lobos, Point Reyes, Adelaida Ranch, and near Garcia Mountain (Bachman and Abbott, 1998). The other basins are younger than the Pigeon Point Formation, and are all east of the Nacimiento fault (Figure 1). Bachman and Abbott (1998) used these distinctive clasts to reconstruct tectonic relationships among the four basins and suggested that Point Lobos was displaced 
northwest about $185 \mathrm{~km}$ from a depositional location just west of Garcia Mountain (Figure 1).

"Smoked salmon" clasts are an unexpected discovery in the Pigeon Point Formation for several reasons. The Pigeon Point Formation is at least 10 Ma older than the other basins; there is no evidence at Pigeon Point of the distinctive granodiorite exposed near Point Lobos, Point Reyes, and in the La Panza Range near Garcia Mountain (Compton, 1966; Ross, 1984); and there are few of the dark quartzite clasts otherwise common at the four comparative locations (Bachman and Abbott, 1988).

\section{Synthesis of Depositional Environment}

This synthesis encompasses the three units depicted in the composite stratigraphic column of Figure 3: the Pescadero felsite, the Pigeon Point Formation and the Vaqueros(?) Formation. Petrographic and chemical analysis done for this thesis was combined with available isotopic, paleontologic and palynologic data for these units.

The Pescadero felsite is inferred by Ernst at al. (in press) as erupted into accretionary complex or forearc basin strata. As described earlier, chemical analysis constrains such strata to be of somewhat primitive affinity. 
The Pigeon Point Formation is interpreted by Lowe $(1979,2004)$ as a submarine canyon-fan system. Molluscan assemblages in the formation (Elder and Saul, 1993) are inferred by the authors to indicate deposition in a warm-temperate to subtropical environment. Paleomagnetic data summarized by Whidden et al. (1998) suggest that this depositional latitude was $\sim 22^{\circ}$ south of its current location. Although neither paleontologic nor palynologic evidence rules this out, data is not available for potentially correlative fossils at such latitudes. A relatively nearby source is required for the tonalite clasts of the Pigeon Point Formation, while a more distal source is likely for the "smoked salmon" clasts. Since the potentially correlative "smoked salmon" clasts are all found in younger basins, east of the Nacimiento fault, fluvial transport of more than $150 \mathrm{~km}$ is required to transport such clasts from their unknown original source to both the correlative basins east of the Nacimiento Fault and to the Pigeon Point Formation.

During one or more compressive events of the Paleogene, the Pigeon Point Formation was folded, uplifted and eroded. Subsequently, a transtensional environment supported the $\sim 22$ Ma deposit of the unconformably overlying shallow marine Vaqueros(?) Formation. A relatively nearby source is required for the angular boulders of transitional granodiorite at the base of the formation. A somewhat more distant source is possible for the more evolved, rounded granite clasts in the conglomerate section of the Vaqueros(?) Formation. Basaltic volcanics 
are present in the uppermost unit of the Vaqueros(?) Formation, some of which are inferred to be subaqueous (Taylor, 1988).

\section{Speculative Reconstruction}

As depicted in Figure 11, it is speculated that the Pigeon Point Formation may have been deposited at a location $\sim 100 \mathrm{~km}$ south of what is now San Diego (PP1), translated northwest to a location outboard of the north Channel Islands (PP2) and finally northwest to its current location (PP3). An analogy for part of this journey is made with the Eocene Poway clast depositional system (Abbott and Smith, 1989). Its source location is in Sonora, Mexico (PC1) and conglomeratic Poway clast deposits are now located near San Diego (PC2) and in a submarine fan now exposed in the northern Channel Islands (PC3).

One of several issues associated with this speculative reconstruction is that it requires rotation of the Pigeon Point block. Whereas Joyce (1981) suggested that some sections are rotated, and post-Miocene clockwise rotation of about 49 degrees within the Purisima Formation in the Pigeon Point block was inferred by Holm and Verosub (1987), Champion et al. (1984) noted no significant rotation within the Pigeon Point Formation. 


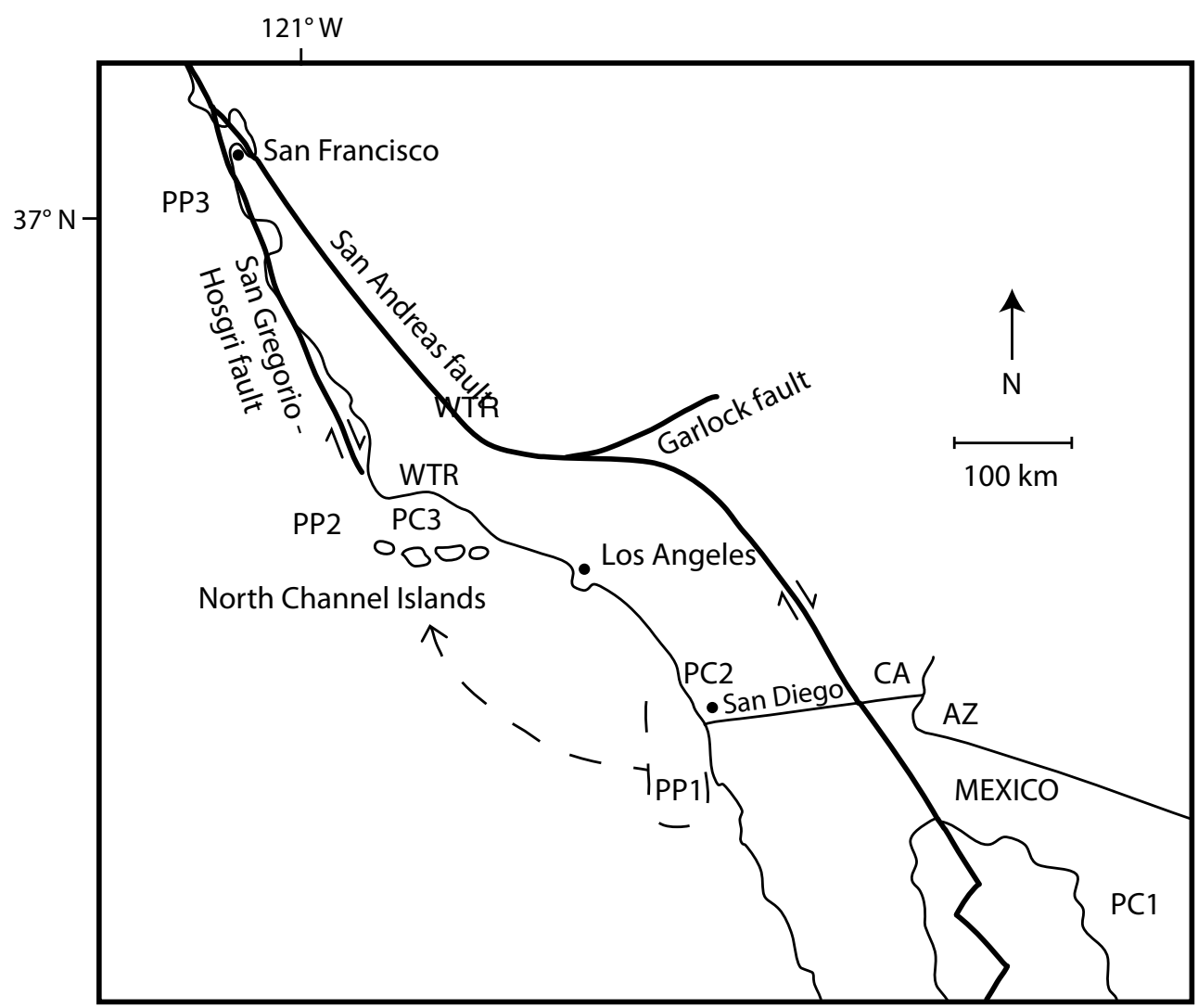

Figure 11. Speculative reconstruction. WTR: western Transverse Ranges. PP1: Pigeon Point Formation depositional location. PP2: location at 10 Ma. PP3: current location. PC1, 2, 3: Dismembered segments of Poway clast depositional system, after Abbott and Smith (1989).

Pigeon Point Formation depositional location PP1 is a site of accretionary or forearc basin strata that could partially melt to produce the Pescadero felsite, consistent with the age distribution of zircons in the felsite (Ernst et al., in press). 
The nearby western Peninsular Ranges batholith includes relatively primitive 130105 Ma tonalites (Early and Silver, 1973; Gromet and Silver, 1987; Gastil, 1993). These tonalites could have provided part of the detritus to the accretionary area at PP1 consistent with the chemical profile of the much younger Pescadero felsite, and are also inferred to be the source for the granitoid clasts present in the Pigeon Point Formation conglomerates. No Late Cretaceous volcanic rocks are known in the Peninsular Ranges that could be the offset remains of the Pescadero felsite. This speculative reconstruction does not help constrain provenance of the Late Jurassic "smoked salmon" clasts, nor does it restore the Late Cretaceous Pigeon Point Formation to be geographically close to known late Paleocene-early Eocene depositional basins of the clasts. Such clasts are exceedingly rare in the Pigeon Point Formation. During the Late Cretaceous, material from the "smoked salmon" source location may not have been readily available or, if it was, perhaps only a few clasts were transported to the formation via unknown fluvial or ocean current systems.

The paleolatitude inferred by location PP1 satisfies the warm-temperate to subtropical climate required by the molluscan assemblages (Elder and Saul, 1993) and is also consistent with the latitude suggested by palynological studies Frederiksen (1990). It is too far north to support the paleomagnetic restoration suggested by Whidden et al. (1998). 
The Pigeon Point Formation was subsequently uplifted, tilted and eroded. The 50 m.y. hiatus between deposits of the Pigeon Point Formation and those of the unconformably overlying Vaqueros(?) Formation coincides with the latest Cretaceous through Eocene period of Laramide flat-slab subduction and shortening (e.g. Coney and Reynolds, 1977).

At $\sim 27 \mathrm{Ma}$, the East Pacific Rise intersected the trench, initiating a change from subduction to transtension (e.g., Atwater, 1970; Atwater and Stock, 1998). Volcanism associated with transtension is the source for the $\sim 22$ Ma basaltic units present in the upper stratigraphy of the Vaqueros(?) Formation. An unknown, local tectonic disruption in the Peninsular Ranges may have delivered transitional granodiorite to the base of the formation. There is no known local source for the more evolved rounded granitic clasts present in the formation.

The dashed outline of location PP1 represents the restored western Transverse Ranges block, including the north Channel Islands (Luyendyk, 1980, 1998; Nicholson et al., 1994; Atwater and Stock, 1998). This block has been extended to the south to encompass the proposed depositional site of the Pigeon Point block. Luyendyk (1998) noted that ages of the volcanic units of the northern Channel Islands progressed from $\sim 19$ Ma in the west to $\sim 16$ Ma in the east (Table 6). Restoration of the Channel Islands places the most western location as the most southern location. Luyendyk (1998) inferred from age progression that rifting initiated at the most southern location and propagated north. Whereas the oldest 
volcanic unit exposed on the northern Channel Islands is $\sim 19 \mathrm{Ma}$, I propose that volcanism could have initiated at $\sim 22$ Ma if the Vaqueros(?) Formation restores to a position outboard (west) of the San Miguel Islands (Table 6).

Table 6. Volcanic ages, north Channel Islands and Vaqueros(?) basalts. Summarized from Wilson et al., 2005, and references therein. All ages approximate.

WEST

\begin{tabular}{|l|l|l|l|l|l|}
\hline Location & $\begin{array}{l}\text { Vaqueros(?) } \\
\text { Pescadero } \\
\text { Beach }\end{array}$ & $\begin{array}{l}\text { San Miguel } \\
\text { Island }\end{array}$ & $\begin{array}{l}\text { Santa Rosa } \\
\text { Island }\end{array}$ & $\begin{array}{l}\text { Santa Cruz } \\
\text { Island }\end{array}$ & $\begin{array}{l}\text { Anacapa } \\
\text { Island }\end{array}$ \\
\hline Age & $22 \mathrm{Ma}$ & $19-17 \mathrm{Ma}$ & $19-18 \mathrm{Ma}$ & $17-16 \mathrm{Ma}$ & $16 \mathrm{Ma}$ \\
\hline Method & $\begin{array}{l}\text { K-Ar on } \\
\text { plagioclase }\end{array}$ & $\begin{array}{l}{ }^{40} \mathrm{Ar} /{ }^{39} \mathrm{Ar} \\
\text { whole-rock } \\
\text { on basalt }\end{array}$ & $\begin{array}{l}{ }^{40} \mathrm{Ar} /{ }^{39} \mathrm{Ar} \\
\text { whole-rock } \\
\text { on diabase } \\
\text { intrusions }\end{array}$ & $\begin{array}{l}{ }^{40} \mathrm{Ar} /{ }^{99} \mathrm{Ar} \\
\text { whole-rock } \\
\text { on andesite; } \\
\text { also on } \\
\text { plagioclase }\end{array}$ & $\begin{array}{l}{ }^{40} \mathrm{Ar} /{ }^{39} \mathrm{Ar} \\
\text { onole-rock } \\
\text { on basalt; } \\
\text { also on } \\
\text { plagioclase }\end{array}$ \\
\hline
\end{tabular}

Rotation of the western Transverse Ranges was substantially completed by $\sim 10 \mathrm{Ma}$, which positioned the Pigeon Point block at the western edge of the Western Transverse Ranges block a this time, within the broad western North America dextral shear zone. It is suggested that slip on undefined offshore right-lateral faults, together with dextral slip on the San Gregorio-Hosgri fault transported the Pigeon Point block to its current location. 


\section{CONCLUSIONS}

Original petrographic and chemical analyses for this thesis combined with the synthesis of previous work by others shed new light on the Pigeon Point Formation and the inferred tectonic history of southwestern California since the Late Cretaceous.

Petrographic work identified potential Pescadero felsite clasts in the Pigeon Point Formation and subsequent chemical analysis confirmed the match. This helps to clarify the relationship between the two units and also further constrains the depositional environment of the underlying Pescadero felsite. Petrography was also instrumental in the identification of potential "smoked salmon" clasts in the Pigeon Point Formation conglomerates and chemical analyses support the tentative correlation to other locations in the Coast Ranges. Because this highly durable clast is identified in a few other basins but their original source location is not known, this did not significantly constrain the depositional environment of the Pigeon Point Formation. Finally, petrography was also key in the identification of the composition of the granitoid clasts in the Pigeon Point Formation as well as two different types of granitoid clasts in the overlying Vaqueros(?) Formation. The compositional information about these three different types of granitoids, combined 
with previous isotope work by others, provides constraints on the depositional location of the Pigeon Point and Vaqueros(?) Formations.

Extensive literature review and synthesis brought the work of many geologic disciplines to bear on the longstanding problem of the depositional location of the Pigeon Point Formation and its related overlying and underlying units. Speculative reconstructions done for this thesis broached the uncertain territory of fault slip in southwestern California during the Paleogene. 


\section{REFERENCES CITED}

Abbott, P.L. and Peterson, G. L., 1978, Effects of abrasion durability on conglomerate clast populations: Examples from Cretaceous and Eocene conglomerates of the San Diego area, California: Journal of Sedimentary Petrology, v. 48, no. 1, p. 3042.

Abbott, P.L. and Smith, T.E., 1989, Sonora, Mexico, source for the Eocene Poway conglomerate of southern California: Geology, v. 17, p. 329-332.

Atwater, T.M., 1970, Implications of plate tectonics for the Cenozoic tectonic evolution of western North America: Geological Society of America Bulletin, v. 81, p. 3513-3536.

Atwater, T. M., and Stock J.M., 1998, Pacific-North America plate tectonics of the Neogene south- western United States-An update, Int. Geol. Rev., 40, 375-402.

Bachman, W. R., and Abbott, P. L., 1988, Lower Paleocene conglomerates in the Salinian block, in Filewicz, M. V., and Squires, R. L., eds., Paleogene Stratigraphy, west coast of North America: West Coast Paleogene Symposium, Society of Economic Paleontologists and Mineralogists, Pacific Section, p. 135-150.

Brabb, E. E., Graymer, R.W., and Jones, D.L., 2000, Geologic Map and Map Database of the Palo Alto 30' x 60' Quadrangle, California: U. S. Geological Survey Miscellaneous Field Studies Map MF-2332b http://greenwood.cr.usgs.gov/pub/mf-maps/mf-2332/

Burnham, K., 1998c. Preliminary comparison of two upper Cretaceous conglomerates: the strata of Anchor Bay and an unnamed unit east of the Pilarcitos fault, San Mateo County, California: a contribution to the paleogeography of the region of the San Andreas fault system [M.S. thesis]: Palo Alto, California, Stanford University, 103 pp.

Burnham, K., 2005, Point Lobos to Point Reyes: evidence of $\sim 180 \mathrm{Km}$ offset on the San Gregorio and Northern San Andreas Faults, in Stevens, C. and Cooper, J., eds., Cenozoic deformation in the central Coast Ranges, California: Society for Sedimentary Geology, Fieldtrip guidebook and volume for the joint meeting of the Cordilleran section - GSA and Pacific Section - AAPG, Book 97, p. 1-29.

Burnham, K., 2009, Predictive model of San Andreas fault system paleogeography, Late Cretaceous to early Miocene, derived from detailed multidisciplinary conglomerate correlations: Tectonophysics, v. 464, p. 195-225.

Clark, J.C., Brabb, E.E., Greene, H.G., and Ross, D.C., 1984, Geology of Point Reyes Peninsula and implications for San Gregorio fault history, in Crouch, J.K., and 
Bachman, S.B., eds., Tectonics and sedimentation along the California margin: Pacific Section, SEPM (Society for Sedimentary Geology), Volume 38, p. 67-85.

Clark, J.C., 1998, Neotectonics of the San Gregorio Fault Zone: Age dating controls on offset history and slip rate [abstract]: American Association of Petroleum Geologists Bulletin, v. 82, no. 5A, p. 844-845.

Clark, J.C., and Brabb, E.E., 1978, Stratigraphic contrasts across the San Gregorio fault, Santa Cruz Mountains, West-central California: California Division of Mines and Geology Special Report 137, p. 3-12.

Champion, D.E., C.S. Gromme, and D.G. Howell, 1981, Paleomagnetic study of the Upper Cretaceous Pigeon Point Formation, in Upper Cretaceous and Paleocene Turbidites, Central California Coast, Book 20, edited by V. Frizzell, Pac. Sect. SEPM, Santa Barbara, Calif. P. 53-59

Champion, D.E., Howell, D.G., and Gromme, C.S., 1984, Paleomagnetic and geologic data indicating $2500 \mathrm{~km}$ of northward displacement for the Salinian and related terranes, California, J. Geophys. Res., v. 89, p. 7736-7752.

Cole, R.B., and Stanley, R.G.,1998, Volcanic rocks of the Santa Maria province, California: U.S. Geological Survey Bulletin 1995-R, p. R1-R35.

Compton, R.R., 1966, Granitic and metamorphic rocks in the Salinian block, California Coast Ranges, in E.H. Bailey, ed., Geology of Northern California: Calif. Div. of Mines Geol. Bull. 190, p. 277-287.

Coney, P.J., and Reynolds, S.J., 1977, Cordilleran Benioff zones: Nature, v. 270, p. 403-405.

Davis, F.F., 1955, Mines and mineral resources of San Mateo County, California: California Journal of Mines and Geology, v. 51, no. 4, p. 401-458.

Dickinson, W. R., Ducea, M., Rosenberg, L. I., Greene, H. G., Graham, S. A., Clark, J. C., Weber, G.E., Kidder, S., Ernst, W.G., and Brabb, E.E., 2005, Net dextral slip, Neogene San Gregorio-Hosgri fault zone, coastal California: Geologic evidence and tectonic implications: GSA Special Paper 391, 43p.

Dunkel, C. A. (1997), Año Nuevo Basin, in 1995 National Assessment of United States Oil and Gas Resources Assessment of the Pacific Outer Continental Shelf Region, OCS Rep. MMS 97-0019, edited by C. A. Dunkel and K. A. Piper, Miner. Manage. Serv., Camarillo, Calif. P. 75-83

Early, T.O., and Silver, L.T., 1973, Rb-Sr isotopic systematics in the Peninsular Ranges batholith of southern and Baja California: Eos (Transactions, American Geophysical Union), v. 54, p. 494. 
Elder, W. P., and Saul, L. R., 1993, Paleogeographic implications of molluscan assemblages in the Upper Cretaceous Pigeon Point Formation, California, in Dunne, G. C. and McDougall, K. A., eds., Mesozoic paleogeography of the Western United States - II: Pacific Section, SEPM, Book 71, p. 171-186.

Ernst, W.G., Martens, U., McLaughlin, R.J., Clark, J., and Moore, D.E., 2009, Significance of U-Pb zircon ages from the Pescadero and Cambria Felsites, West-central California Coast Ranges: Geological Society of America Abstracts with Programs, v. 41 , no. 7, p. 644 .

Ernst, W.G., Martens, U., McLaughlin, R.J., Clark, J., and Moore, D.E., in press, Zircon U$\mathrm{Pb}$ age of the Pescadero felsite: a Late Cretaceous igneous event in the forearc, west-central California Coast Ranges: Geological Society of America Bulletin

Ernst, W. G., and Hall, C. A., Jr., 1974, Geology and petrology of the Cambria Felsite, a new Oligocene formation, west-central California Coast Ranges: Geological Society of America Bulletin, v. 85, p. 523-532.

Frederiksen, N.O., 1990, Late Cretaceous pollen from the Salinian(?) suspect terrane at Pigeon Point, San Mateo County, California: U.S. Geological Survey Open-File Report 90-523, 18 p.

Gastil, R.G., 1993, Prebatholithic history of peninsular California, in Gastil, R.G., and Miller, R.H., eds., The prebatholithic stratigraphy of peninsular California: Boulder, Colorado, Geological Society of America Special Paper 279, p. 145-156.

Gilbert, W. G., 1973a, Franciscan rocks near Sur fault zone, Northern Santa Lucia Range, California. Geological Society of America Bulletin v. 84, p. 3317-3328

Gromet, L.P., and Silver, L.T., 1987, REE variations across the Peninsular Ranges batholith: Implications for batholithic petrogenesis and crustal growth in magmatic arcs: Journal of Petrology, v. 28, no. 1, p. 75-125.

Grove, K., 1989, Upper Cretaceous conglomerates from the Salinian terrane, westcentral California, in Colburn, I.P., Abbott, P.L., and Minch, J., eds., Conglomerates in basin analysis: A symposium dedicated to A.O. Woodford: Pacific Section, SEPM (Society for Sedimentary Geology), Book 62, p. 143-160.

Hall C.A., Jr., Jones, D.L., and Brooks, S.A., 1959, Pigeon Point Formation of Late Cretaceous age, San Mateo County, California: Geological Notes, AAPG Bulletin v. 43 , no. 12, p. 2855-2865.

Hall, C.A., Jr., 1991, Geology of the Point Sur-Lopez Point region, Coast Ranges, California; A part of the Southern California Allochthon: Geological Society of America Special Paper 266, 40 p. 
Hart, E.W., 1976, Basic Geology of the Santa Margarita Area, San Luis Obispo County, California: California Division of Mines and Geology Bulletin 199, 45 p.

Holm, E.J., and Verosub, K.L., 1987, Large-scale, post-Miocene rotation of the Pigeon Point block, San Mateo County [abs.]: Eos (Transactions, American Geophysical Union), v. 68, no. 44, p. 1254.

Howard, J.L., 1993, The statistics of counting clasts in rudites: a review, with examples from the upper Palaeogene of southern California, USA. Sedimentology v. 40 , p. 157-114.

Howell, D.G., Vedder, J.G., McLean, H., Joyce, J.M., Clarke Jr., S.H., Smith, G., 1977. Review of Cretaceous geology, Salinian and Nacimiento blocks, Coast Ranges of central California. In: Howell, D.G., Vedder, J.G., McDougall, K.A. (Eds.), Cretaceous geology of the California Coast Ranges, west of the San Andreas Fault; Pacific Coast paleogeography field guide. Society Economic Paleontologists and Mineralogist, Pacific Section, Los Angeles, California, USA, p. 1-46.

Howell, D.G., and Vedder, J.G., 1978, Late Cretaceous paleogeography of the Salinian block, California, in Howell, D.G., and McDougall, K.A., eds., Mesozoic Paleogeography of the Western United States: Los Angeles, Pacific Section, SEPM (Society for Sedimentary Geology), Pacific Coast Paleogeography Symposium 2, p. 523-534.

Howell, D. G. and J. M. Joyce, 1981, Field guide to the Upper Cretaceous Pigeon Point Formation: Upper Cretaceous and Paleocene turbidites, central California coast, annual meeting Pacific Section SEPM Field Trip 6.

Jacobson, C. E., Grove, M., Pedrick, J. N., Barth, A. P., Marsaglia, K. M., Gehrels, G. E., and Nourse, J. A., in press, Late Cretaceous-early Cenozoic tectonic evolution of the southern California margin inferred from provenance of trench and forearc sediments: Geological Society of America Bulletin.

Jennings, C.W., compiler, 1977, Geologic map of California: California Division of Mines and Geology, scale 1:750,000, 1 sheet.

Johnson, D.M., Hooper, P.R., and Conrey, R.M., 1999, XRF Analysis of rocks and minerals for major and trace elements on a single low dilution Li-tetraborate fused bead, Advances in X-ray Analysis: GeoAnalytical Lab, Washington State University, v. 41 p. 843-867. http://www.sees.wsu.edu/Geolab/note/xrf.html

Joyce, J.M., 1981, A deformational history of the Pigeon Point Formation: Upper Cretaceous and Paleocene turbidites, central California coast, annual meeting Pacific Section SEPM Field Trip 6. 
Kellerhals, R. and Gray, D.I., 1971, Sampling procedures for coarse fluvial sediments, Journal of the Hydraulics division, American Society of Civil Engineers, v. 97, p. 1165-1180.

Kistler, R.W., 1990, Two different lithosphere types in the Sierra Nevada, California, in Anderson, J.L., ed., The nature and origin of Cordilleran magmatism: Geological Society of America Memoir 174, p. 271-281.

Kistler, R.W. and Champion, D. E. 2001, Rb-Sr Whole-Rock and Mineral Ages, K-Ar, 40Ar/39Ar, and U-Pb Mineral ages, and Strontium, Lead, Neodymium, and Oxygen Isotopic Compositions for Granitic Rocks from the Salinian Composite Terrane, California: U.S. Geological Survey Open-File Report 01-453.

Lee-Wong, F., and Howell, D.G., 1977, Petrography of Upper Cretaceous sandstones in the Coast Ranges of California, in Howell, D.G., Vedder, J.G., and McDougall, K., eds., Cretaceous geology of the California Coast Ranges west of the San Andreas fault: Pacific Section, SEPM (Society for Sedimentary Geology), Pacific Coast Paleogeography Field Guide 2, p. 47-55.

Lowe, D.R., 1979, Stratigraphy and sedimentology of the Pigeon Point Formation, San Mateo County, California, in Nilsen, T.H., and Brabb, E.E., eds., Geology of the Santa Cruz Mountains, California: Geological Society of America, Cordilleran Section, Field Trip Guidebook, p. 17-29.

Lowe, D.R., 2004, Deep-water sandstones: Submarine canyon to basin plain, western California: Pacific Section AAPG and AAPG, Pacific Section AAPG Publication GB 79, $79 \mathrm{p}$.

Lund, S.P., Bottjer, D.J., Whidden, K.J., Powers J.E., and Steele, M.C., 1991, Paleomagnetic evidence for Paleogene terrane displacements and accretion in southern California, in Eocene Geologic History, edited by Abbott, P.L. and May, J.A., Pac. Sect. SEPM, p. 99-106, Santa Barbara, Calif.

Luyendyk, B. P., Gans P.B., and M. J. Kamerling, M.J. 1998, 40Ar/39Ar geochronology of southern California Neogene volcanism, in Contributions to the Geology of the Northern Channel Islands, Southern California, vol. MP-45, edited by P. W. Weigand, pp. 9 - 35, Pac. Sect., Amer. Assoc. of Pet. Geol., Bakersfield, Calif.

Nicholson, C., Sorlien, C.C., Atwater, T. western Transverse Ranges, and initiation of the San Andreas transform as a low-angle fault system, Geology, v. 22, p. 491495.

Page, B. M.,1981, The Southern Coast Ranges, in Ernst, W.G., ed., The geotectonic development of California (Rubey Volume I): Prentice-Hall, Englewood Cliffs, NJ, p. 329-417. 
Powell, R.E., 1993, Balanced palinspastic reconstruction of pre-late Cenozoic paleogeology, southern California, in Powell, R.E., Weldon, R.J., and Matti, J.C., eds., The San Andreas fault system: Displacement, palinspastic reconstruction, and geologic evolution: Geological Society of America Memoir 178, p. 1-106.

Powell, II, C.L., Barron, J.A., Sarna-Wojicicki, Clark, J.C., Perry, F.A., Brabb, E.E., Fleck, R.J., 2007, Age, Stratigraphy, and Correlations of the Late Neogene Purisima Formation, Central California Coast Ranges: U.S. Geological Survey Professional Paper 1740.

Rollingson, H.R. 1993, Using Geochemical Data: Evaluation, Presentation, Interpretation. Pearson Education Unlimited, Essex, England, 352 p.

Ross, D.C., 1984. Possible correlations of basement rocks across the San Andreas, San Gregorio-Hosgri, and Rinconada-Reliz-King City faults, California. U.S. Geological Survey Professional paper P-1317, 37 p.

Sanquini, A., Metzger E. P., and McLaughlin, R. J., 2010, A petrographic link between the Late Cretaceous Pigeon Point conglomerate and felsic volcanic rocks near Pescadero, California: Geological Society of America, Abstracts with Programs, v. 42, no. 4, p. 74 .

Saul, L. R., \& Squires, R. L. 2008. Volutoderminae (Gastropoda: Volutidae) of Coniacian through Maastrichtian age from the North American Pacific Slope. Journal of Paleontology, v. 82(2), p. 213-237.

Seiders, V. M. 1983, Correlation and provenance of upper Mesozoic chert-rich conglomerate of California: Geological Society of America Bulletin, v. 94, p. 875888.

Seiders, V.M., Cox, B.F., 1992. Place of origin of the Salinian block, California, as based on clast compositions of Upper Cretaceous and Lower Tertiary conglomerates. U.S. Geological Survey, Professional Paper P-1526, 80 p.

Stanley, R. G., D. S. Wilson, and P. A. McCrory (2000), Locations and ages of middle Tertiary volcanic centers in coastal California, U.S. Geol. Surv. Open File Rep., 00$154,27 \mathrm{p}$.

Sun, S.S., and McDonough, W.F., 1989, Chemical and isotopic systematics of oceanic basalts; implications for mantle composition and processes, in Saunders, A.D., and Norry, M.J., eds., Magmatism in the ocean basins: Geological Society [London] Special Publication 42, p. 313-345.

Taylor, F.E., 1988, The geology of Middle Tertiary rocks at Pescadero State Beach and Point Año Nuevo (M.S. Thesis): Fresno, California, California State University, 188 p. 
Taylor, E., 1990, Syndepositional magmatism within the Vaqueros(?) Formation (Upper Oligocene-Lower Miocene) of Pescadero State Beach and Punta Año Nuevo, San Mateo County, California, in Garrison, R.E., Greene, H.G., Hicks, K.R., Weber, G.E., and Wright, T.L., eds., Geology and tectonics of the central California coast region, San Francisco to Monterey: Pacific Section, American Association of Petroleum Geologists, Book GB67, p. 57-70.

Tyler, J.H., 1972, Pigeon Point Formation: an Upper Cretaceous shoreline succession, central California coast: Journal of Sedimentary Petrology, v. 42, no. 3, p. 537557.

Underwood, M.B., Laughland, M.B., Shelton, K.L., and Sedlock, R.L., 1995, Thermalmaturity trends within Franciscan rocks near Big Sur, California: Implications for offset along the San Gregorio-San Simeon-Hosgri fault zone: Geology, v. 23, p. 839-842.

Valencia-Moreno, M., Ruiz, J., and Ochoa-Landin, L., Martinez-Serrano, R. and VargasNavarro, P., 2003, Geochemistry of the Coastal Sonora batholith, Northwestern Mexico: Can. J. Earth Sci., v. 40, p. 819-831.

Vedder, J.G., Howell, D.G. and McLean, H., 1983, Stratigraphy, sedimentation, and tectonic accretion of exotic terranes, southern Coast Ranges, California, in Watkins, J.A. and Drake, C.L., eds., Studies in continental margin geology: American Association of Petroleum Geologists Memoirs, v. 34, p. 471-496.

Vedder, J. G., H. McLean, and R. G. Stanley,1991, Paleogeographic implications of an erosional remnant of Paleogene rocks southwest of the Sur-Nacimiento fault zone, southern Coast Ranges, California, Geological Society of America Bulletin, v. 103, p. 941-952.

Whidden, K.J., Lund, S.P., Bottjer, D.J., Champion, D., and Howell, D.G., 1998, Paleomagnetic evidence that the central block of Salinia is not a far-traveled terrane: Tectonics, v. 17, p. 329-343.

Williams, H., Turner, J.F., and Gilbert, C.M., 1982, Petrography: An introduction to the study of rocks in thin section. Second edition, San Francisco, W.H. Freeman. 626 p.

Wilson, D. S., P. A. McCrory, and R. G. Stanley, 2005, Implications of volcanism in coastal California for the Neogene deformation history of western North America, Tectonics, 24, TC3008, doi:10.1029/2003TC001621.

Wood D.A., 1980, The application of a Th-Hf-Ta diagram to problems of tectonomagmatic classification and to establishing the nature of crustal contamination of basaltic lavas of the British Tertiary volcanic province, Earth and Planetary Science Letters, v. 50, p. 11-30. 